\title{
International Union of Basic and Clinical Pharmacology. LXXXII: Nomenclature and Classification of Hydroxy-carboxylic Acid Receptors (GPR81, GPR109A, and GPR109B)
}

Stefan Offermanns, Steven L. Colletti, Timothy W. Lovenberg, Graeme Semple, Alan Wise, ${ }^{1}$ and Adriaan P. IJzerman

Department of Pharmacology, Max-Planck-Institute for Heart and Lung Research, Bad Nauheim, Germany (S.O.); Medical Faculty, Goethe University Frankfurt, Frankfurt, Germany (S.O.); Department of Medicinal Chemistry, Merck Research Laboratories, Merck \& Co., Inc., West Point, Pennsylvania (S.L.C.); Johnson \& Johnson Pharmaceutical Research \& Development, L.L.C., San Diego, California (T.W.L.); Arena Pharmaceuticals, San Diego, California (G.S.); Scottish Enterprise, Edinburgh, United Kingdom (A.W.); and Division of Medicinal Chemistry, Leiden/Amsterdam Center for Drug Research, Leiden University, Leiden, the Netherlands (A.P.IJ.)

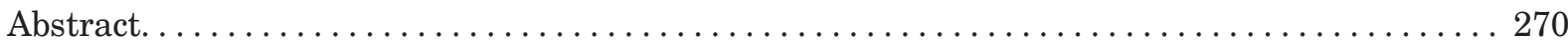

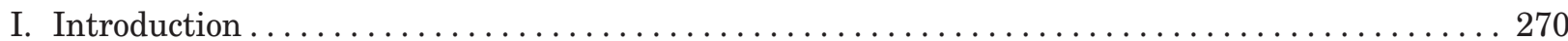

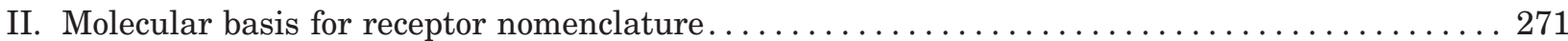

A. Cloning of cDNAs encoding hydroxy-carboxylic acid receptors . . . . . . . . . . . . 271

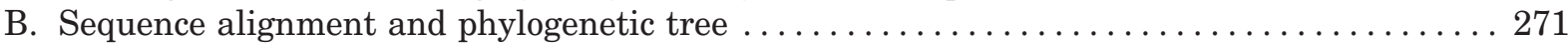

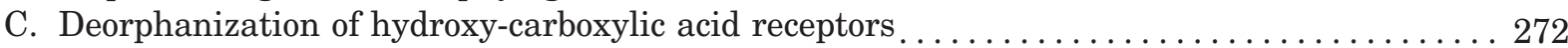

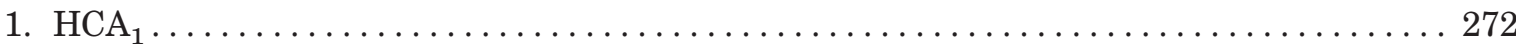

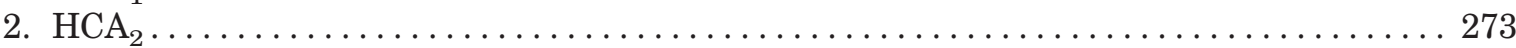

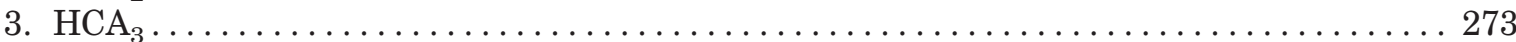

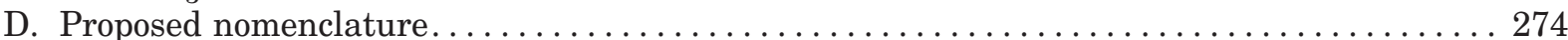

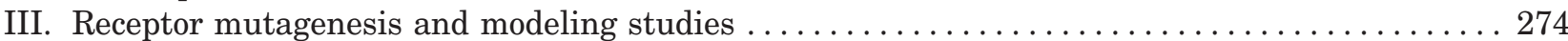

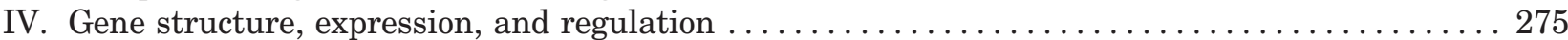

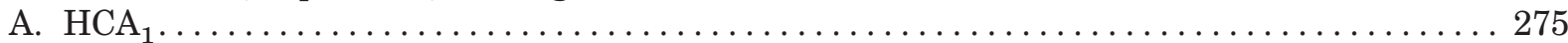

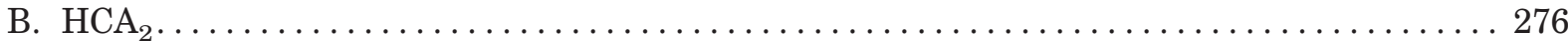

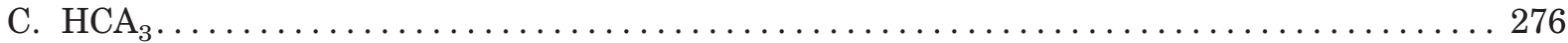

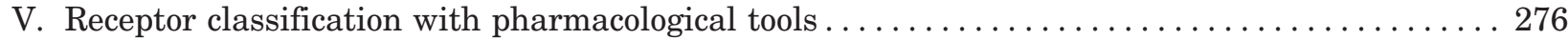

A. Structure-activity relationships for the $\mathrm{HCA}_{2}$ receptor $\ldots \ldots \ldots \ldots \ldots \ldots \ldots \ldots \ldots \ldots \ldots$

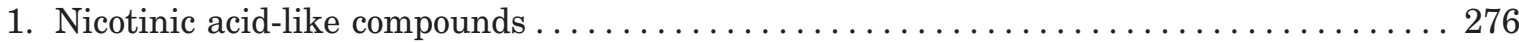

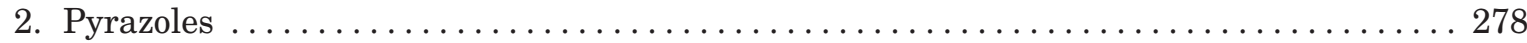

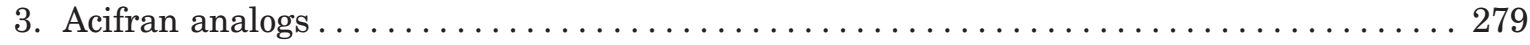

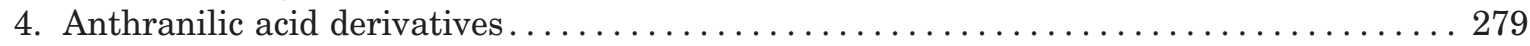

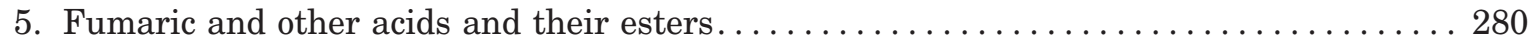

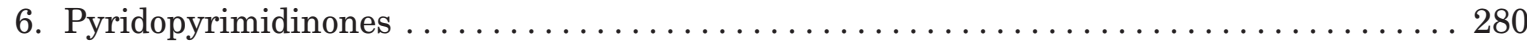

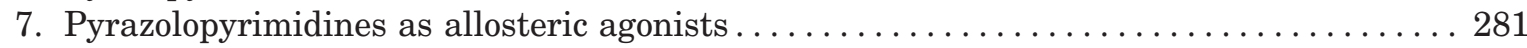

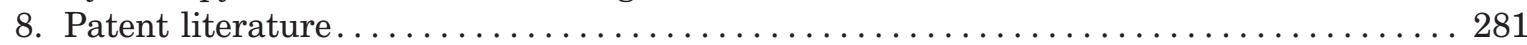

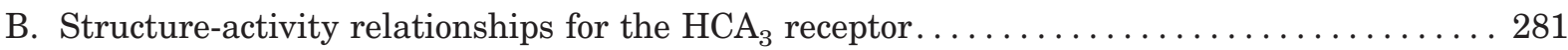

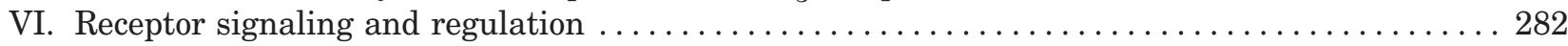

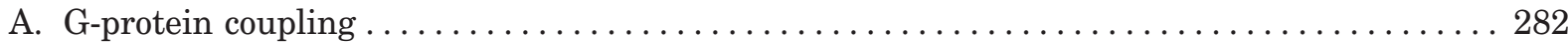

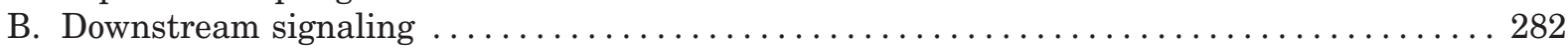

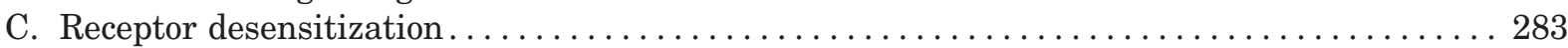

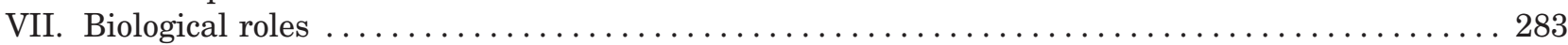

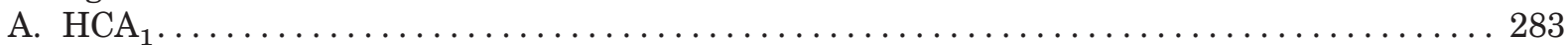

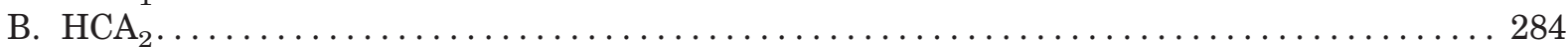

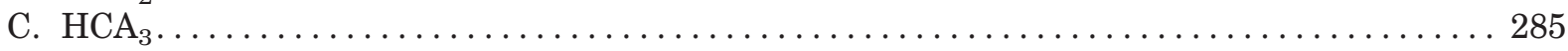

Address correspondence to: Stefan Offermanns, Department of Pharmacology, Max-Planck-Institute for Heart and Lung Research, Ludwigstrasse 43, 61231 Bad Nauheim, Germany. E-mail: stefan.offermanns@mpi-bn.mpg.de

${ }^{1}$ Current affiliation: TPP Global Development, Edinburgh, United Kingdom.

This article is available online at http://pharmrev.aspetjournals.org.

doi:10.1124/pr.110.003301. 
VIII. Therapeutic potential of hydroxy-carboxylic acid receptor ligands $\ldots \ldots \ldots \ldots \ldots \ldots \ldots \ldots 285$

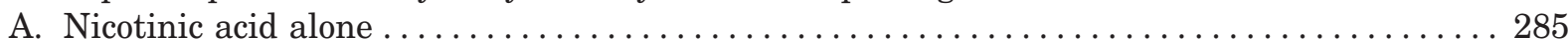

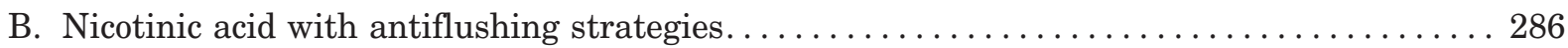

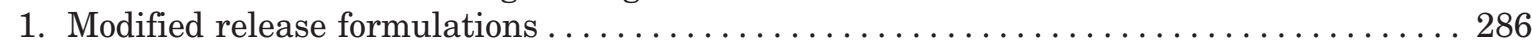

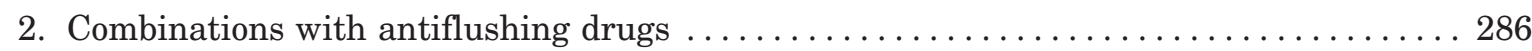

C. Nicotinic acid in combination with other lipid-altering drugs $\ldots \ldots \ldots \ldots \ldots \ldots \ldots \ldots 286$

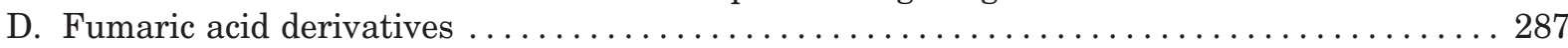

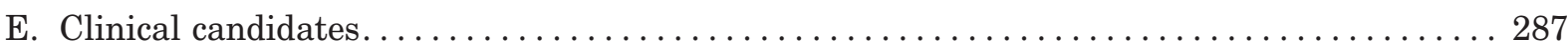

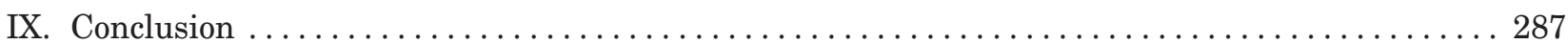

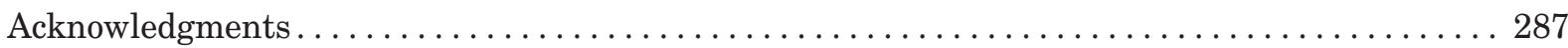

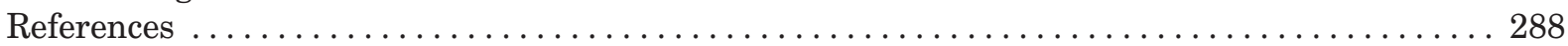

\begin{abstract}
The G-protein-coupled receptors GPR81, GPR109A, and GPR109B share significant sequence homology and form a small group of receptors, each of which is encoded by clustered genes. In recent years, endogenous ligands for all three receptors have been described. These endogenous ligands have in common that they are hydroxy-carboxylic acid metabolites, and we therefore have proposed that this receptor family be named hydroxy-carboxylic acid (HCA) receptors. The $\mathrm{HCA}_{1}$ receptor (GPR81) is activated by 2-hydroxy-propanoic acid (lactate), the $\mathrm{HCA}_{2}$ receptor (GPR109A) is a receptor for the ketone body 3-hydroxy-butyric acid, and the $\mathrm{HCA}_{3}$ receptor (GPR109B) is activated by the $\beta$-oxidation intermediate 3-hydroxy-octanoic acid. $\mathrm{HCA}_{1}$ and $\mathrm{HCA}_{2}$ receptors are found in most mammalian species, whereas the $\mathrm{HCA}_{3}$
\end{abstract}

receptor is present only in higher primates. The three receptors have in common that they are expressed in adipocytes and are coupled to $\mathrm{G}_{\mathrm{i}}$-type $\mathrm{G}$-proteins mediating antilipolytic effects in fat cells. $\mathrm{HCA}_{2}$ and $\mathrm{HCA}_{3}$ receptors are also expressed in a variety of immune cells. $\mathrm{HCA}_{2}$ is a receptor for the antidyslipidemic drug nicotinic acid (niacin) and related compounds, and there is an increasing number of synthetic ligands mainly targeted at $\mathrm{HCA}_{2}$ and $\mathrm{HCA}_{3}$ receptors. The aim of this article is to give an overview on the discovery and pharmacological characterization of HCAs, and to introduce an International Union of Basic and Clinical Pharmacology (IUPHAR)-recommended nomenclature. We will also discuss open questions regarding this receptor family as well as their physiological role and therapeutic potential.

\section{Introduction}

In 1955, Rudolf Altschul discovered that the administration of relatively high doses of the vitamin nicotinic acid (niacin) leads to a decrease in plasma cholesterol levels by approximately $10 \%$ in healthy volunteers and by more than $20 \%$ in patients with hypercholesterolemia (Altschul et al., 1955). The fact that nicotinamide, which is equivalent to nicotinic acid as a vitamin, had no effect on plasma cholesterol levels indicated that this effect was unrelated to the function of nicotinic acid as a vitamin. Meanwhile, nicotinic acid has been well established as an antidyslipidemic drug (Carlson, 2005).

Soon after the discovery of the pharmacological effects of nicotinic acid, research efforts to understand the mechanism of action were directed at adipose tissue, because the most immediate effect of nicotinic acid on lipid metabolism is a decrease in free fatty acid levels that results from an antilipolytic effect (Carlson and Oro, 1962; Carlson, 1963). Thereafter, nicotinic acid was shown to reduce cAMP levels in adipose tissue (Butcher et al., 1968), an effect that resulted from $\mathrm{G}_{\mathrm{i}}$-mediated inhibition of adenylyl cyclase (Aktories et al., 1980a). At that time, the hypothesis was formulated that nicotinic acid acts through a $\mathrm{G}_{\mathrm{i}}$-coupled receptor (Aktories et al., 1980b), a concept that was later supported by the demonstration of specific binding sites for nicotinic acid on plasma membranes of adipocytes and spleen cells (Lorenzen et al., 2001).

In 2003, the human and mouse orphan G-proteincoupled receptors HM74A and PUMA-G, respectively, were discovered to be receptors for nicotinic acid (Soga et al., 2003; Tunaru et al., 2003; Wise et al., 2003); shortly thereafter, the ketone body 3-hydroxy-butyrate was shown to be an endogenous ligand for GPR109A $1^{1}$ (Taggart et al., 2005). Since then, many synthetic ligands of GPR109A have been developed. In addition, for the closely related receptors GPR81 and GPR109B (see Table 1 and Figs. 1 and 2), endogenous and synthetic ligands have been discovered and generated.

In this review, we introduce a new nomenclature for the receptors GPR81, GPR109A, and GPR109B. Because all known endogenous ligands of GPR81, GPR109A, and GPR109B are hydroxy-carboxylic acids, the receptor family is called hydroxy-carboxylic acid receptors with

\footnotetext{
${ }^{1}$ Abbreviations: CHO, Chinese hamster ovary; $\mathrm{CysLT}_{2}$, cysteinylleukotriene 2; ERK, extracellular signal-regulated kinase; ETE, eicosatetraenoic acid; GPR, G protein receptor; GRK, G-protein-coupled receptor kinase; GTP $\gamma \mathrm{S}$, guanosine $5^{\prime}-O$-(3-thio)triphosphate; HCA, hydroxy-carboxylic acid; HDL, high-density lipoprotein; INF, interferon; LDL, low-density lipoprotein; MEF, monoethyl ester of fumaric acid; MK-0354, 3-(1H-tetrazol-5-yl)-1,4,5,6-tetrahydrocyclopentapyrazole; MMF, monomethyl ester of fumaric acid; PG, prostaglandin; $\mathrm{PLA}_{2}$, phospholipase $\mathrm{A}_{2}$; PPAR, peroxisome proliferatoractivated receptor; TM, transmembrane; TNF, tumor necrosis factor.
} 
TABLE 1

Current HCA receptor nomenclature and receptor properties

For further details, see IJzerman et al. (2010).

\begin{tabular}{|c|c|c|c|}
\hline Properties & $\mathrm{HCA}_{1}$ & $\mathrm{HCA}_{2}$ & $\mathrm{HCA}_{3}$ \\
\hline Previous names/aliases & $\begin{array}{l}\text { GPR81, GPR104, TA-GPCR, } \\
\text { LACR, FKSG80 }\end{array}$ & $\begin{array}{l}\text { GPR109A, HM74a (human), PUMA-G } \\
\text { (mouse), HM74b, NIACR1 }\end{array}$ & GPR109B, HM74, NIACR2 \\
\hline Genomic location & $\begin{array}{l}\text { (mouse) } \\
\text { 12q24.31 (human), } 5 \mathrm{~F}\end{array}$ & $12 \mathrm{q} 24.31$ (human), $5 \mathrm{~F}$ (mouse) & 12q24.31 (human) \\
\hline Amino acid length & 346 (human), 343 (mouse) & 363 (human), 360 (mouse) & 387 (human) \\
\hline $\begin{array}{l}\text { Naturally occurring specific } \\
\text { agonists }\left(\mathrm{pEC}_{50}\right)\end{array}$ & 2-OH-propanoate $(2.5-2.8)$ & $\begin{array}{l}\text { 3-OH-butyrate (3.1), nicotinic acid } \\
(6.6-7.2)\end{array}$ & $\begin{array}{l}\text { 3-OH-octanoate (5.1), 2-OH-octanoate (5.4), } \\
\text { D-phenylalanine (5.0), D-tryptophan } \\
(5.4)\end{array}$ \\
\hline $\begin{array}{l}\text { Specific synthetic agonists } \\
\left(\mathrm{pEC}_{50}\right)\end{array}$ & & acipimox $(5.2-5.6)$ & $\begin{array}{l}\text { 1-Isopropylbenzo-triazole-5-carboxylic acid } \\
\text { (6.4), 5-methyl-5-(5-methyl-thio-phen-3- } \\
\text { yl)-4-oxo-4,5-dihydro-furan-2-carboxylic } \\
\text { acid (6.7) }\end{array}$ \\
\hline G-protein coupling & $\mathrm{G}_{\mathrm{i}} / \mathrm{G}_{\mathrm{o}}$ & $\mathrm{G}_{\mathrm{i}} / \mathrm{G}_{\mathrm{o}}$ & $\mathrm{G}_{\mathrm{i}} / \mathrm{G}_{\mathrm{o}}$ \\
\hline Expression in human tissue & Adipocytes & $\begin{array}{l}\text { Adipocytes, macrophages, neutrophils, } \\
\text { epidermal Langerhans cells, } \\
\text { keratinocytes, intestinal epithelial } \\
\text { cells }\end{array}$ & $\begin{array}{l}\text { Adipocytes, neutrophils, macrophages, } \\
\text { intestinal epithelial cells }\end{array}$ \\
\hline Cellular function & Inhibition of lipolysis & $\begin{array}{l}\text { Inhibition of lipolysis, activation of } \\
\text { immune cells }\end{array}$ & $\begin{array}{l}\text { Inhibition of lipolysis, activation of } \\
\text { immune cells }\end{array}$ \\
\hline $\begin{array}{l}\text { Phenotype of mice lacking } \\
\text { receptor }\end{array}$ & $\begin{array}{l}\text { Reduced insulin-induced } \\
\text { antilipolysis }\end{array}$ & $\begin{array}{l}\text { Lack of nicotinic acid effects on lipid } \\
\text { plasma levels and of nicotinic acid- } \\
\text { induced flushing }\end{array}$ & \\
\hline
\end{tabular}

the individual names $\mathrm{HCA}_{1}$ (GPR81), $\mathrm{HCA}_{2}$ (GPR109A), and $\mathrm{HCA}_{3}$ (GPR109B) (see Table 1). We also describe the cellular, physiological, and pathophysiological role of the receptors, their pharmacological characterization, and their therapeutic potential.

\section{Molecular Basis for Receptor Nomenclature}

\section{A. Cloning of cDNAs Encoding Hydroxy-carboxylic} Acid Receptors

The $\mathrm{HCA}_{3}$ receptor (GPR109B) was the first hydroxycarboxylic acid receptor whose cDNA was cloned and analyzed (Nomura et al., 1993). In search of new putative leukocyte chemotactic peptide receptors, Nomura et al. (1993) used degenerate oligonucleotide primers representing conserved cDNA regions encoding transmembrane domains of the human receptors for interleukin-8, complement factor $5 \mathrm{a}$ and $N$-formyl peptides to perform polymerase chain reactions on a human monocyte cDNA library. Full-length clones were isolated from the same cDNA library using the obtained polymerase chain reaction amplificate. One of the cDNAs encoding a new G-protein-coupled receptor was called HM74 ( $\mathrm{HCA}_{3} /$ GPR109B), and the receptor was shown to be expressed in monocytes and neutrophils. It was also noted that the $\mathrm{HCA}_{3}$ sequence differed considerably from that of leukocyte chemotactic peptide receptors, suggesting that this receptor had a different ligand.

The $\mathrm{HCA}_{1}$ receptor (GPR81) was first found by a database search in which expressed sequence tag and highthroughput genomic sequences databases were analyzed for homologies to sequences of various known G-proteincoupled receptors using the TBLAST algorithm (Lee et al., 2001). The $\mathrm{HCA}_{1}$ receptor cDNA was then cloned from a human bacterial artificial chromosome genomic clone localized to chromosome 12q. Lee et al. (2001) noticed the high homology to the $\mathrm{HCA}_{3}$ receptor (GPR109B, HM74) and also observed that the genes encoding $\mathrm{HCA}_{1}$ and $\mathrm{HCA}_{3}$ receptors are near each other on the same human bacterial artificial chromosome.

The $\mathrm{HCA}_{2}$ receptor (GPR109A) was originally identified in mice in a search for genes differentially expressed in interferon- $\gamma(\mathrm{INF}-\gamma)$ /tumor necrosis factor- $\alpha$ (TNF- $\alpha)$ stimulated macrophages (Schaub et al., 2001). Schaub et al. (2001) used a subtractive hybridization strategy to identify cDNAs present in a cDNA library generated from the murine macrophage cell line ANA-1 stimulated for $16 \mathrm{~h}$ with INF- $\gamma$ and TNF- $\alpha$ but absent from cDNA libraries derived from untreated ANA-1 cells or from IFN- $\gamma$ stimulated embryonic fibroblasts. The expression of the $\mathrm{HCA}_{2}$ receptor in response to INF- $\gamma$ and TNF- $\alpha$ was verified subsequently in various mouse macrophage cell lines, and the murine $\mathrm{HCA}_{2}$ receptor was therefore designated PUMA-G (protein up-regulated in macrophages by IFN- $\gamma$ ). Expression of $\mathrm{HCA}_{2}$ could also be induced in the spleens of mice after infection with $\mathrm{Lis}$ teria monocytogenes. Human and rat $\mathrm{HCA}_{2}$ receptors were cloned after the discovery of $\mathrm{HCA}_{3}$ as a low-affinity receptor for nicotinic acid during a search for novel paralogs of the $\mathrm{HCA}_{3}$ receptor (Soga et al., 2003; Wise et al., 2003).

\section{B. Sequence Alignment and Phylogenetic Tree}

The $\mathrm{HCA}_{1}$ receptor (GPR81) has been shown to be expressed in humans and rodents, and, based on genomic sequences of various species, seems to be present in most mammals as well as in fish (C. Kuei, J. Yu, J. Zhu, J. Wu, T. Lovenberg, and C. Liu, manuscript in preparation). Likewise, the $\mathrm{HCA}_{2}$ receptor (GPR109A), which exhibits substantial homology to the $\mathrm{HCA}_{1}$ receptor (approximately 50\% amino acid sequence identity), is 

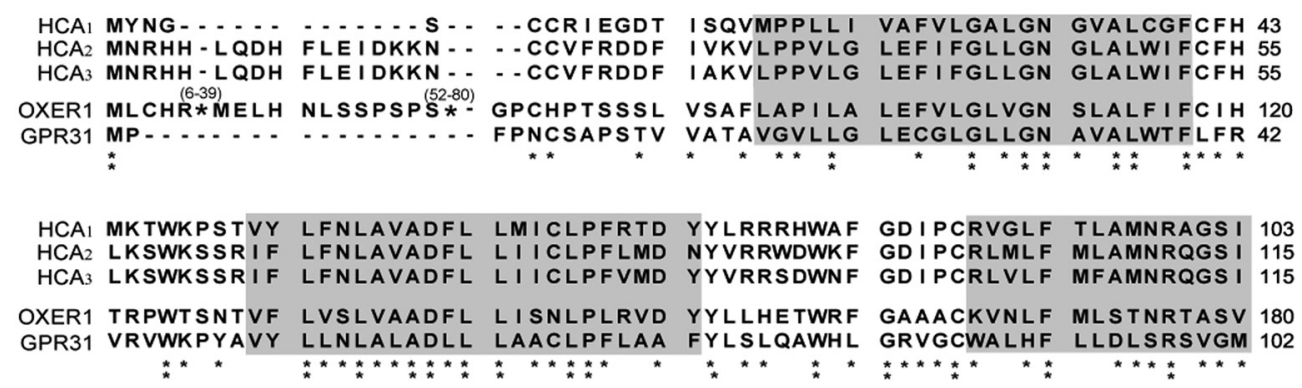

HCA 1 VFLTVVAADR YFKVVHPHHA VNTISTRVAA GIVCTLWALV ILGTVYLLLE NHLCVQETAV 163 HCA 2 IFLTVVAVDR YFRVVHPHHA LNKISNRTAA IISCLLWGIT IGLTVHLLKK KMPIQNGGAN 175 HCA3 IFLTVVAVDR YFRVVHPHHA LNK ISNWTAA I ISCLLWGIT VGLTVHLLKK KLLIQNGPAN 175 OXER1 VFLTAIALNR YLKVVQPHHV LSRASVGAAA RVAGGLWVGI LLLNGHLLLS TF.....SGP 235 GPR31 AFLAAVALDR YLRVVHPRLK VNLLSPQAAL GVSGLVWLLM VALTCPGLLI SEAAQNSTR- 161

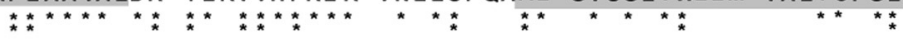

HCAI SCESFIM-- - - ESANGWHDI MFQLEFFMPL GIILFCSFKI VWSLRRR-QQ LARQARMKKA 218 HCA LCSSFS I..- - CHTFQWHEA MFLLEFFLPL GI ILFCSARI IWSLRQR-Q- MDRHAKIKRA 229 HCA 3 VCISFSI - - - CHTFRWHEA MFLLEFLLPL GIILFCSARI IWSLRQR-Q- MDRHAKIKRA 229 OXER1 SCLSYRVGTK PSASLRWHQA LYLLEFFLPL ALILFAIVSI GLTIRNR--G LGGQAGPQRA 293 GPR31 - CHSFYSRAD GSFSIIWQEA LSCLQFVLPF GLIVFCNAGI IRALQKRLRE PEKQPKLQRA 220 ****
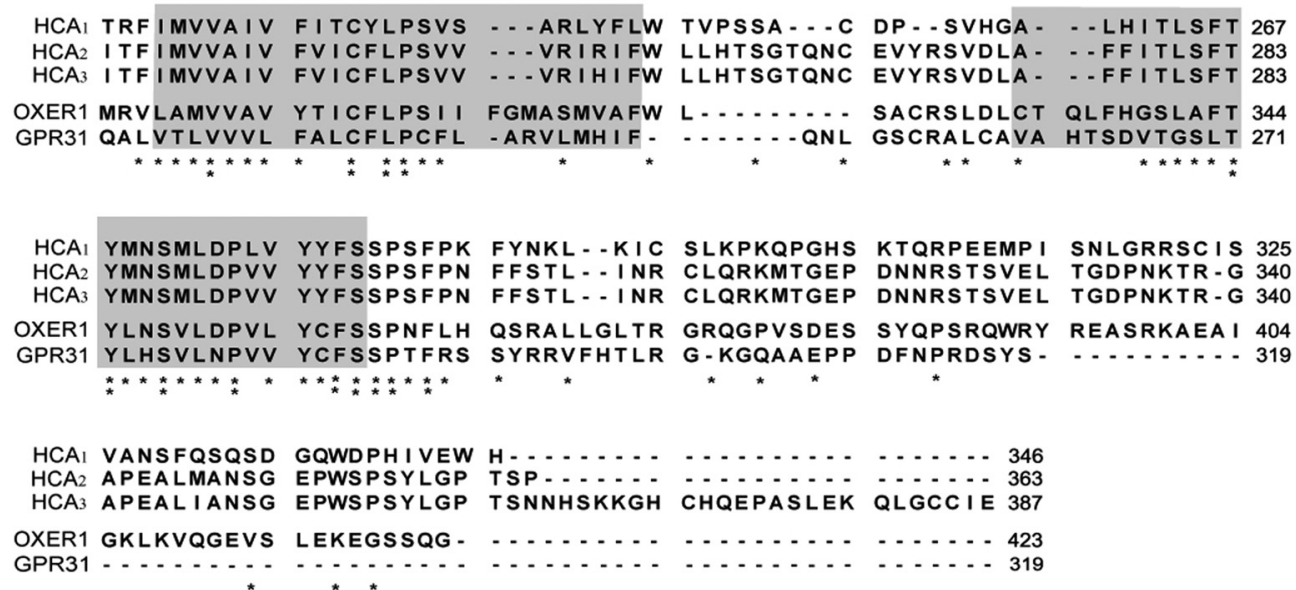

FIG. 1. Amino acid sequence alignment of $\mathrm{HCA}_{1}, \mathrm{HCA}_{2}$, and $\mathrm{HCA}_{3}$ as well as of the related receptors GPR31 and OXER1 (TG1019, GPR170) based on the Clustal V method. Transmembrane regions are indicated by gray boxes. Two short sequences in the N-terminal part of OXER1 (residues 6-39 and 52-80) have been omitted to facilitate the alignment (gaps are indicated by asterisks). Positions with identical amino acids in $\mathrm{HCA}_{1}, \mathrm{HCA}_{2}$, and $\mathrm{HCA}_{3}$ are marked by one asterisk (*), positions with identical residues in all five receptors are indicated by two asterisks $(* *)$.

present in mammalian species. $\mathrm{HCA}_{2}$ and $\mathrm{HCA}_{3}$ receptors are highly homologous, being $95 \%$ identical on the protein level (see Figs. 1 and 2). The receptors differ by 15 amino acids that cluster in the first and second extracellular loops as well as in the outer parts of transmembrane regions 2 and 3 . In addition, the $\mathrm{HCA}_{3}$ receptor has an extended $\mathrm{C}$ terminus containing 24 additional amino acids. In contrast to $\mathrm{HCA}_{1}$ and $\mathrm{HCA}_{2}$ receptors, the $\mathrm{HCA}_{3}$ receptor is not present in rodents. The analysis of available genomic sequences shows an ortholog of the human $\mathrm{HCA}_{3}$ receptor gene only in chimpanzees, whereas lower primates, such as rhesus monkeys, do not carry a gene encoding an $\mathrm{HCA}_{3}$ receptor. Thus, the $\mathrm{HCA}_{3}$ receptor is obviously the result of rather recent gene duplication. Several single-nucleotide polymorphisms in the coding regions of genes encoding $\mathrm{HCA}_{2}$ and $\mathrm{HCA}_{3}$ receptors occur with heterozygosity ratios of 0.14 to 0.46 (Zellner et al.,
2005). It is not clear, however, whether any of these variations alters the physiological or pharmacological functions of the receptor proteins.

\section{Deorphanization of Hydroxy-carboxylic Acid Receptors}

1. $H C A_{1}$. The receptor $\mathrm{HCA}_{1}(\mathrm{GPR} 81)$ remained classified as an orphan receptor until 2008, when lactate was identified as a ligand of the $\mathrm{HCA}_{1}$ receptor (Cai et al., 2008). Lactate was shown to stimulate GTP $\gamma$ S-binding in a $\mathrm{HCA}_{1}$ receptor-dependent fashion with an $\mathrm{EC}_{50}$ of $1.3 \mathrm{mM}$. Inhibition of forskolin-stimulated cAMP production in $\mathrm{CHO}$ cells transfected with $\mathrm{HCA}_{1}$ occurred with an $\mathrm{EC}_{50}$ of $2.1 \mathrm{mM}$. Lactate did not activate the $\mathrm{HCA}_{2}$ or $\mathrm{HCA}_{3}$ receptor, and L-lactate was twice as potent and efficacious as D-lactate. Although various other short-chain fatty acids had no effect on the $\mathrm{HCA}_{1}$ 
A

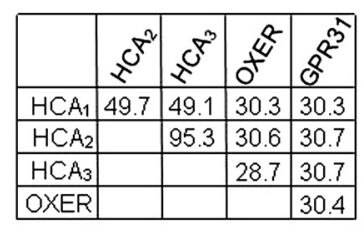

amino acid sequence identity (\%)

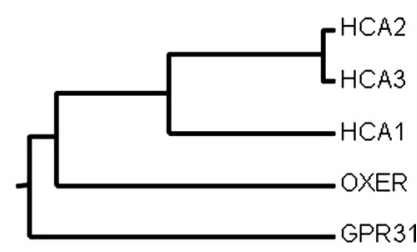

B

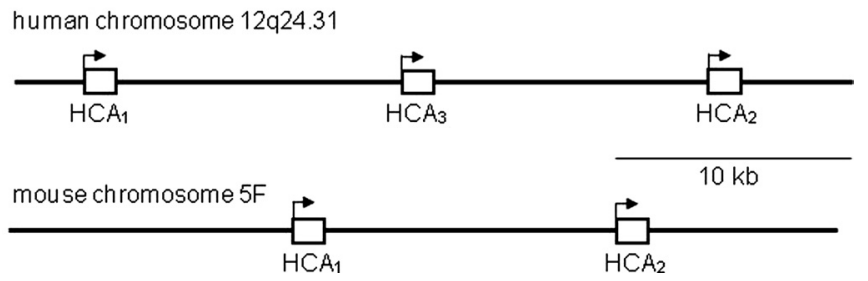

FIG. 2. A, phylogenetic tree and percentage amino acid sequence identity of the human hydroxy-carboxylic acid receptors $\mathrm{HCA}_{1}, \mathrm{HCA}_{2}$, and $\mathrm{HCA}_{3}$ as well as of the most related human receptors GPR31 and the 5-oxo-ETE receptor OXER1 (GPR170, TG1019). Data are based on an alignment by the Clustal $\mathrm{W}$ method. B, schematic representation of the genomic organization of the genes encoding hydroxy-carboxylic acid receptors.

receptor, sodium propionate activated the receptor with an $\mathrm{EC}_{50}$ of $3 \mathrm{mM}$. Because of the relatively low plasma levels of propionate, this activity is unlikely to be of physiological relevance. In a parallel study, Liu et al. (2009) identified lactate as an agonist of the $\mathrm{HCA}_{1}$ receptor by testing extracts from different rat tissues and by subsequent chromatographic purification and identification of lactate from porcine brain extracts. The reported $\mathrm{EC}_{50}$ values for lactate-induced GTP $\gamma \mathrm{S}$-binding and inhibition of cAMP formation were slightly higher (5 and $4.2 \mathrm{mM}$, respectively). Liu et al. (2009) also showed that lactate is a specific agonist for the human $\mathrm{HCA}_{1}$ receptor and that $\mathrm{HCA}_{1}$ receptors cloned from various mammalian species, including mouse, rat, dog, pig, cow, and monkey, responded in a comparable manner to lactate. Furthermore, the zebrafish $\mathrm{HCA}_{1}$ receptor seems to have a higher affinity for lactate at $1 \mathrm{mM}$ (C. Kuei, J. Yu, J. Zhu, J. Wu, T. Lovenberg, and C. Liu, manuscript in preparation). In addition to L-lactate, $\alpha$-hydroxybutyrate, glycolate, $\alpha$-hydroxyisobutyrate, and $\gamma$-hydroxybutyrate were shown to activate $\mathrm{HCA}_{1}$ with low potency $\left(\mathrm{EC}_{50}\right.$ values $\left.5-15 \mathrm{mM}\right)$. In contrast, D-lactate, $\alpha$-hydroxycaproic acid, maleate, tartrate, and propionate are weak partial agonists of the $\mathrm{HCA}_{1}$ receptor, whereas nicotinic acid, pyruvate, $\beta$-hydroxybutyrate, acetate, GABA, and butyrate are not active. In addition, Liu et al. (2009) found that dichloroacetate and trifluoroacetate are partial agonists of the $\mathrm{HCA}_{1}$ receptor. The basic pharmacological properties of the $\mathrm{HCA}_{1}$ receptor were later confirmed independently (Ahmed et al., 2010). The low ligand affinity of lactate for $\mathrm{HCA}_{1}$ is not without precedent. The $\mathrm{Ca}^{2+}$-sensing receptor is also activated by millimolar concentrations of its agonist; however, this receptor is a class C GPCR with somewhat different activation mech- anisms compared with class A, to which HCA receptors belong (Hofer and Brown, 2003).

Of all the reported naturally occurring agonists of $\mathrm{HCA}_{1}$, only L-lactate reaches levels sufficient to activate the receptor. Basal plasma concentrations of lactate are in the range of 0.5 and $2 \mathrm{mM}$ (Huckabee, 1958; Marbach and Weil, 1967; Niessner and Beutler, 1973) and would be too low to lead to full $\mathrm{HCA}_{1}$ activation. However, under certain conditions, systemic lactate concentrations as well as localized concentrations (e.g., in fat tissue) increase severalfold (Kreisberg, 1980; DiGirolamo et al., 1992; Hagström-Toft et al., 1997). During intensive exercise, lactate plasma levels are as high as 10 to $20 \mathrm{mM}$ (Turrell and Robinson, 1942; Osnes and Hermansen, 1972).

2. $\mathrm{HCA}_{2}$. Taggart et al. (2005) reported the deorphanization of the $\mathrm{HCA}_{2}$ receptor (GPR109A) as a receptor for the ketone body 3-hydroxy-butyrate. Racemic (DL)-3hydroxy-butyrate activated GTP $\gamma$ S binding through the human and mouse receptors with an $\mathrm{EC}_{50}$ values of 0.7 and $0.8 \mathrm{mM}$, respectively. The $\mathrm{EC}_{50}$ for the L-enantiomer was approximately 2 -fold higher than that for the physiologically relevant D-enantiomer, which stimulated GTP $\gamma$ S-binding with an $\mathrm{EC}_{50}$ of $1.6 \mathrm{mM}$ through the human receptor (Taggart et al., 2005). Other ketone bodies, such as acetoacetate or acetone, were without activity. Several short-chain fatty acids, such as pentanoic, hexanoic, octanoic, and butyric acids, were also shown to activate the human $\mathrm{HCA}_{2}$ receptor with $\mathrm{EC}_{50}$ values of 0.4 to $1.6 \mathrm{mM}$. However, physiological concentrations are unlikely to reach sufficient levels to activate the receptor. 3-Hydroxy-butyrate had no activity on $\mathrm{HCA}_{1}$ or $\mathrm{HCA}_{3}$ receptors. 3-Hydroxy-butyrate levels are between 20 and $200 \mu \mathrm{M}$ under normal conditions. However, after fasting for 2 to 3 days, ketone body levels in the plasma increase to approximately $2 \mathrm{mM}$ and can reach up to 6 to $8 \mathrm{mM}$ after prolonged starvation (Owen et al., 1969), levels sufficient to fully activate the $\mathrm{HCA}_{2}$ receptor.

3. $\mathrm{HCA}_{3}$. Despite the high homology of $\mathrm{HCA}_{2}$ and $\mathrm{HCA}_{3}$ receptors, they show quite different binding properties for nicotinic acid and related substances, and various synthetic ligands specific for the $\mathrm{HCA}_{3}$ receptor have been generated (see section V). 2- and 3-Hydroxylated medium-chain fatty acids, in particular 3-hydroxyoctanoate, have been shown to be specific agonists of $\mathrm{HCA}_{3}$, acting through the receptor with an $\mathrm{EC}_{50}$ of 4 to $8 \mu \mathrm{M}$ (Ahmed et al., 2009a). 3-Hydroxy-octanoate was not able to activate $\mathrm{HCA}_{1}$ or $\mathrm{HCA}_{2}$ receptors, and a shortening or extension of the chain length of 3-hydroxyoctanoate by more than two carbon atoms resulted in a complete loss of activity at the $\mathrm{HCA}_{3}$ receptor. 3 - $\mathrm{Hy}$ droxy-hexanoate, 3-hydroxy-octanoate, and 3-hydroxydecanoate are intermediates of fatty acid $\beta$-oxidation. Under conditions of increased $\beta$-oxidation flux, during starvation, under ketogenic diet, or in patients with diabetic ketoacidosis, 3-hydroxy-octanoate plasma con- 
centrations reach levels sufficient to activate the $\mathrm{HCA}_{3}$ receptor (Costa et al., 1998; Jones et al., 2002; Ahmed et al., 2009a).

It is noteworthy that various aromatic D-amino acids, such as D-phenylalanine, D-tryptophan, and D-kynurenine, were shown to decrease cAMP levels by acting through the $\mathrm{HCA}_{3}$ receptor with $\mathrm{EC}_{50}$ values between 10 and $100 \mu \mathrm{M}$ (Irukayama-Tomobe et al., 2009). Aromatic D-amino acids had no effect on the $\mathrm{HCA}_{2}$ receptor. The physiological enantiomers L-phenylalanine, L-tryptophan, and L-kynurenine did not activate $\mathrm{HCA}_{3}$ at concentrations of $100 \mu \mathrm{M}$ (Irukayama-Tomobe et al., 2009). Because D-amino acids are extremely rare, it is unclear whether the ability of aromatic D-amino acids to activate the $\mathrm{HCA}_{3}$ receptor is of physiological or pathophysiological significance.

\section{Proposed Nomenclature}

In the past, various names were given to the receptors $\mathrm{HCA}_{1}$ (GPR81), $\mathrm{HCA}_{2}$ (GPR109A), and $\mathrm{HCA}_{3}$ (GPR109B) (see Table 1). After the identification of the $\mathrm{HCA}_{2}$ receptor (GPR109A) as a receptor for nicotinic acid, this receptor family has been called the "nicotinic acid receptor family" or "niacin receptor family." However, the name nicotinic acid receptor family is not appropriate because nicotinic acid (niacin) is not an endogenous ligand and because only $\mathrm{HCA}_{2}$ (GPR109A) and neither $\mathrm{HCA}_{3}$ (GPR109B) nor $\mathrm{HCA}_{1}$ (GPR81) is a receptor for nicotinic acid. Endogenous ligands for all three members of the family have been described (see section II.C). Because all these endogenous ligands are hydroxycarboxylic acids, we propose that this receptor family be called the "hydroxy-carboxylic acid (HCA) receptor family," which currently has three members: $\mathrm{HCA}_{1}, \mathrm{HCA}_{2}$, and $\mathrm{HCA}_{3}$ (see Table 1).

The G-protein-coupled receptors most closely related to the HCA receptor family are the orphan receptor GPR31 and the 5-oxo-6,8,11,14-eicosatetraenoic acid (5oxo-ETE) receptor OXER1 (Fig. 1 and 2) (Zingoni et al., 1997; Hosoi et al., 2002; Bjarnadóttir et al., 2006). An arginine residue in transmembrane helix 3 , which has been proposed to represent an anchor point of the carboxylic group of HCA receptor ligands (Tunaru et al., 2005), is conserved not only among HCA receptors but also in GPR31 and the 5-oxo-ETE receptor (Fig. 1). These homologies suggest that GPR31 and OXER1 ligands may structurally resemble HCA receptor ligands. Although endogenous ligands for GPR31 are unknown, OXER1 binds not only 5-oxo-ETE but also, with lesser affinity, 5-hydroxy-eicosatetraenoic acid and 5-hydroperoxy-eicosatetraenoic acid (Hosoi et al., 2002; Jones et al., 2003; Brink et al., 2004). Thus, the fact that OXER 1 is activated by a polyunsaturated fatty acid substituted in the 5-position with an oxo, hydroxy, or hydroperoxy group resembles HCA receptors also with regard to its agonistic ligand.

\section{Receptor Mutagenesis and Modeling Studies}

Although the sequence similarity between $\mathrm{HCA}_{2}$ and $\mathrm{HCA}_{3}$ receptors is very high, nicotinic acid is recognized with only low affinity by the $\mathrm{HCA}_{3}$ receptor. In contrast, the antidyslipidemic agent acifran (Cayen et al., 1982) stimulates both the $\mathrm{HCA}_{2}$ and $\mathrm{HCA}_{3}$ receptors, although it has a predilection for the former $\left(\mathrm{EC}_{50}\right.$ values of 1.9 and $90 \mu \mathrm{M}$, respectively). This intriguing observation was the starting point for mutagenesis studies in which chimeras between the two receptors as well as point mutations were introduced (Tunaru et al., 2005). A chimera linking the $\mathrm{N}$-terminal part of the $\mathrm{HCA}_{3}$ receptor and the $\mathrm{C}$-terminal part of the $\mathrm{HCA}_{2}$ receptor at the interface between intracellular loop 2 and TM4 responded well to acifran $\left(\mathrm{EC}_{50}=2 \mu \mathrm{M}\right)$ but was insensitive to nicotinic acid. The same chimera, studied in a later article, responded well to 2-oxo-octanoic acid, a close analog of the endogenous $\mathrm{HCA}_{3}$ receptor ligand 3-hydroxy-octanoic acid, in a manner identical to the wild-type $\mathrm{HCA}_{3}$ receptor (Ahmed et al., 2009a). The "reverse" chimera, in which the N-terminal half was from $\mathrm{HCA}_{2}$, did not respond to 2-oxo-octanoic acid. The second approach of site-directed mutagenesis was applied to both the $\mathrm{HCA}_{2}$ and $\mathrm{HCA}_{3}$ receptors. In the $\mathrm{HCA}_{2}$ receptor, Asn86 and Trp91 (at the interface of TM2 and extracellular loop 1) and Ser178 (in extracellular loop 2) were mutated to Tyr, Ser, and Ile, respectively, which are the corresponding amino acids in the $\mathrm{HCA}_{3}$ receptor. This yielded receptor constructs that did not respond to nicotinic acid any more; acifran kept $\mathrm{HCA} 3$ receptor-like potency. All arginine residues in the $\mathrm{HCA}_{2}$ receptor TM domains, as putative counterparts for the negatively charged carboxylic function in both nicotinic acid and acifran, were also examined. Of the four arginines available, Arg111 present in TM3, when mutated to alanine, rendered the $\mathrm{HCA}_{2}$ receptor completely insensitive to nicotinic acid. This position is equivalent to the well known Asp residue in biogenic amine receptors. Eventually, it was deduced that three more residues may constitute the binding site of nicotinic acid on the $\mathrm{HCA}_{2}$ receptor, Phe180 (extracellular loop 2) and Phe276 and Tyr284 (both present in TM7). A receptor homology model was presented based on rhodopsin's crystal structure (Palczewski et al., 2000). Because the endogenous ligand in rhodopsin, retinal, is quite large compared with nicotinic acid, there is some uncertainty as to how to dock nicotinic acid or other small HCA receptor ligands into the putative binding site. The authors postulated that the pyridine ring of nicotinic acid is embedded between Trp91 and Phe276/Tyr284, and hydrogenbonded via its nitrogen atom to Ser178. Deng et al. (2008) docked an anthranilic acid derivative (Fig. 6a), considerably larger than nicotinic acid, inside an independently constructed $\mathrm{HCA}_{2}$ receptor homology model, also based on the rhodopsin/retinal complex. The ligand was positioned in an extended conformation and sur- 
rounded by residues mainly from TM3, TM5, TM6, and the second extracellular loop. The residues in the binding pocket represent three groups of interactions. First, there is a triad of two arginines and one serine. Arg111 (TM3) and Arg251 (TM6) are thought to form salt bridges with the ligand's carboxylate moiety. Ser178 (extracellular loop 2) is close to the carboxamide fragment in the ligand, forming a hydrogen bond. Secondly, hydrophobic residues coordinate the anisole moiety of the ligand, including Ile254 (TM6), Phe255 (TM6), and Phe276 (TM7). The third group of interactions involves several polar residues at the entrance of the binding pocket, including Asn171 (extracellular loop 2), Ser179 (extracellular loop 2), and His259 (extracellular loop 3). This latter group of amino acids was also postulated to be involved in the interaction with an optimized lead molecule (Fig. 6d; see also Shen et al., 2007b), in which the hydroxyl substituent on the quinoxaline moiety is hydrogen-bonded to Asn171. The recently determined crystal structures of other GPCRs may be of further help in the modeling of the HCA receptors and their binding sites (Cherezov et al., 2007; Jaakola et al., 2008; Warne et al., 2008).

Ahmed et al. (2009a) introduced further mutations into the $\mathrm{HCA}_{2}$ receptor, focusing on positions 86, 91, 103, and 107. Mutation of three of these positions in the $\mathrm{HCA}_{2}$ receptor to the corresponding residues in the $\mathrm{HCA}_{3}$ receptor (N86Y, M103V, L107F) made the receptor fully respond, such as the wild-type $\mathrm{HCA}_{3}$ receptor, to 2-hydroxy-octanoic acid, yet another close analog of the endogenous $\mathrm{HCA}_{3}$ receptor ligand. A very similar mutant (N86Y, W91S, M103V) did not respond at all to 2-hydroxyoctanoic acid. In a separate, single $\mathrm{HCA}_{3}$ receptor mutant (R111A), the response to 2-hydroxy-octanoic acid was completely abrogated too, suggesting that this amino acid is vital for anchoring the acidic group in $\mathrm{HCA}_{3}$ receptor ligands.

The $\mathrm{HCA}_{1}$ receptor was the subject of two recent mutagenesis studies (Ge et al., 2008; Liu et al., 2009). In the first (Ge et al., 2008), a chimeric receptor was constructed that consisted of the $\mathrm{N}$ terminus, all three extracellular loops, and all seven TM domains from the cysteinyl-leukotriene 2 (CysLT2) receptor and all three intracellular loops and the $\mathrm{C}$ terminus from the $\mathrm{HCA}_{1}$ receptor. Leukotriene $\mathrm{D}_{4}$, the cognate ligand for the $\mathrm{CysLT}_{2}$ receptor, was capable of activating this receptor construct through a pertussis toxin-sensitive inhibitory $\mathrm{G}$ protein. This evidence suggests that the $\mathrm{HCA}_{1}$ receptor, an orphan receptor at the time of the experiments, indeed signals via $G_{i}$ proteins, because the wild-type $\mathrm{CysLT}_{2}$ receptor is coupled predominantly to $\mathrm{G}_{\mathrm{q}}$. In adipocytes of transgenic mice expressing the chimeric receptor, leukotriene $\mathrm{D}_{4}$ inhibited lipolysis, measured as a reduction in glycerol release. This effect was not observed in wild-type mice lacking the receptor construct. Nicotinic acid served as a control, administration of which led to an inhibition of lipolysis in all mice.
Liu et al. (2009) performed site-directed mutagenesis of the $\mathrm{HCA}_{1}$ receptor, providing some evidence that conserved key residues in the TM domains make up the binding site for lactate. Four point mutations were separately introduced: R99A (TM3), Y233A (TM6), R240A (TM6), and T267A (TM7). The first amino acid is equivalent to Arg111 in the $\mathrm{HCA}_{2}$ receptor, the putative anchor point for the ligand's carboxylic acid group. All four mutations led to inactive receptors, because lactate did not stimulate $\left.{ }^{35} \mathrm{~S}\right] \mathrm{GTP} \gamma \mathrm{S}$ binding any of these. A receptor homology model based on the structure of rhodopsin structure was presented in which lactate was manually docked to interact with the four amino acids, somewhat at odds with the proposed orientation of nicotinic acid in the $\mathrm{HCA}_{2}$ receptor.

\section{Gene Structure, Expression, and Regulation}

The genes encoding $\mathrm{HCA}_{1}, \mathrm{HCA}_{2}$, and $\mathrm{HCA}_{3}$ receptors are next to each other in tandem on human chromosome $12 q 24.31$ in a configuration in which the gene encoding the $\mathrm{HCA}_{3}$ receptor is flanked by the two other genes (see Fig. 2). In all species known to carry genes for HCA receptors, the coding sequence of the receptors is present on a single exon.

\section{A. $H C A_{1}$}

The $\mathrm{HCA}_{1}$ receptor was originally reported to be expressed in human pituitary tissue (Lee et al., 2001). However, this has never been confirmed. Meanwhile, evidence has been provided that the receptor is primarily expressed in adipocytes (Wise et al., 2003; Ge et al., 2008; Jeninga et al., 2009; Liu et al., 2009; Ahmed et al., 2010). In humans, the $\mathrm{HCA}_{1}$ receptor was found to be most abundantly expressed in brown adipose tissue with also rather high expression in white adipose tissue (Liu et al., 2009). Similar expression patterns were found in mice and in rats. In addition, receptor expression was markedly induced during differentiation of 3T3-L1 preadipocytes (Ge et al., 2008; Jeninga et al., 2009; Liu et al., 2009). Very low levels of $\mathrm{HCA}_{1}$ receptor expression were seen in several other tissues. However, it is not clear whether this is due to specific expression of the $\mathrm{HCA}_{1}$ receptor or to the presence of adipocytes in these tissues. It is noteworthy that in both mouse and human models, it could be shown that thiazolidinediones acting via the nuclear receptor peroxisome proliferator-activated receptor $\gamma(\mathrm{PPAR} \gamma)$ increase the expression of $\mathrm{HCA}_{1}$ receptor mRNA 4- to 5-fold (Jeninga et al., 2009). This effect was shown to be mediated by the binding of the PPAR $\gamma /$ retinoid X receptor heterodimer to a functional PPAR-response element present in the proximal promoter of the $\mathrm{HCA}_{1}$ receptor gene (Jeninga et al., 2009). Jeninga et al. (2009) provided additional data suggesting that the antilipolytic effect of thiazolidinediones is mediated in part through the up-regulation of the $\mathrm{HCA}_{1}$ receptor in adipocytes. 


\section{B. $\mathrm{HCA}_{2}$}

The receptor of $\mathrm{HCA}_{2}$ shows highest expression levels in white and brown adipose tissue in both human and mouse (Soga et al., 2003; Tunaru et al., 2003; Wise et al., 2003). During the differentiation of 3T3-L1 preadipocytes, expression of the $\mathrm{HCA}_{2}$ receptor is induced 1 to 2 days earlier than expression of the $\mathrm{HCA}_{1}$ receptor $(\mathrm{Ge}$ et al., 2008; Jeninga et al., 2009). Similar to $\mathrm{HCA}_{1}$, the expression of the $\mathrm{HCA}_{2}$ receptor is increased by PPAR $\gamma$ activation (Jeninga et al., 2009). Because there is no functional PPAR-response element in the promoter of the $\mathrm{HCA}_{2}$ receptor gene, it has been suggested that the PPAR-response element present in the proximal promoter of the $\mathrm{HCA}_{1}$ receptor gene controls the $\mathrm{HCA}_{2}$ receptor gene promoter (Jeninga et al., 2009).

Apart from adipocytes, expression of the $\mathrm{HCA}_{2}$ receptor is also found in various immune cells, including neutrophils, macrophages, dendritic cells, and epidermal Langerhans cells (Schaub et al., 2001; Benyó et al., 2005; Maciejewski-Lenoir et al., 2006; Kostylina et al., 2008) but not in mouse and human B and T lymphocytes or in human eosinophils (Schaub et al., 2001; Kostylina et al., 2008; Tang et al., 2008). $\mathrm{HCA}_{2}$ receptor expression was not detected in immature bone marrow neutrophils, indicating that induction of $\mathrm{HCA}_{2}$ receptor expression occurs during the late stages of terminal differentiation of neutrophils (Kostylina et al., 2008). Expression of the $\mathrm{HCA}_{2}$ receptor in macrophages can be increased by treatment of cells with IFN- $\gamma$, TNF- $\alpha$, lipopolysaccharide, and $\mathrm{CpG}$ oligodeoxynucleotides, whereas IFN- $\alpha$, IFN- $\beta$, granulocyte macrophage-colony-stimulating factor, interleukin-1, interleukin-12, and interleukin-18 had no effect (Schaub et al., 2001). In primary human monocytes and adhesion-differentiated macrophages, the $\mathrm{HCA}_{2}$ receptor was up-regulated by hypoxia (Knowles et al., 2006).

Expression of the $\mathrm{HCA}_{2}$ receptor has also been reported in the apical membrane of epithelial cells of the small and large intestine. Expression in intestinal epithelial cells seems to be reduced in colon cancer as well as under germ-free conditions (Thangaraju et al., 2009; Cresci et al., 2010). In addition, retinal pigment epithelial cells express the $\mathrm{HCA}_{2}$ receptor, which appears primarily localized to the basolateral membrane of these cells (Martin et al., 2009). On the mRNA level, $\mathrm{HCA}_{2}$ receptor expression has been shown in primary human keratinocytes (Maciejewski-Lenoir et al., 2006; Tang et al., 2008); however, immunohistochemistry failed to demonstrate $\mathrm{HCA}_{2}$ receptor expression in keratinocytes (Maciejewski-Lenoir et al., 2006). Expression of the $\mathrm{HCA}_{2}$ receptor in keratinocytes has recently been shown by genetic and functional approaches (Hanson et al., 2010), and strong $\mathrm{HCA}_{2}$ receptor expression has also been described in the human epidermoid carcinoma cell line A431 (Maciejewski-Lenoir et al., 2006; Zhou et al., 2007). Similar to macrophages, expression of the $\mathrm{HCA}_{2}$ receptor in keratinocytes and keratinocyte cell lines is induced be IFN- $\gamma$ (Tang et al., 2008).

\section{C. $\mathrm{HCA}_{3}$}

Expression of the $\mathrm{HCA}_{3}$ receptor seems to be very similar to that of the $\mathrm{HCA}_{2}$ receptor. The $\mathrm{HCA}_{3}$ receptor is expressed in adipose tissue (Soga et al., 2003; Tunaru et al., 2003; Wise et al., 2003), and this expression can be increased by activation of PPAR (Jeninga et al., 2009). In addition, the $\mathrm{HCA}_{3}$ receptor is expressed in various immune cells, including neutrophils, monocytes, and macrophages (Nomura et al., 1993; Yousefi et al., 2000; Ahmed et al., 2009a; Irukayama-Tomobe et al., 2009). Expression in neutrophils has been shown to be stimulated by granulocyte macrophage-colony-stimulating factor (Yousefi et al., 2000), whereas expression in primary human monocytes and phorbol 12-myristate 13acetate-differentiated THP1 and U937 monocytic cell lines can be increased by hypoxia (Knowles et al., 2006). Evidence has also been provided for the expression of the $\mathrm{HCA}_{3}$ receptor in epithelial cells of the colon (Thangaraju et al., 2009).

\section{Receptor Classification with Pharmacological Tools}

Although nicotinic acid was introduced in humans in the 1950s (Altschul et al., 1955), structure-activity relationships for its target(s) were developed much later. Only in the 1980s did Aktories et al. (1980a, 1983) propose the existence of a specific receptor for nicotinic acid and a related compound, acipimox. Progress being slow, members of the same laboratory explored a few more compounds related to nicotinic acid in a number of receptor assays, using membranes from rat adipocytes and rat spleen (Lorenzen et al., 2001). A few years later, the human $\mathrm{HCA}_{2}$ receptor was cloned (Wise et al., 2003). In that study, a number of nicotinic acid-like compounds were also tested. Therefore, we will use these two studies, the data from which are gathered in Table 2, as the starting point for this paragraph. In Fig. 3, the chemical structures of these compounds are represented. Because most efforts have been directed toward the $\mathrm{HCA}_{2}$ receptor, we will discuss the synthetic ligands for this receptor first, followed by the more restricted information on the $\mathrm{HCA}_{3}$ receptor. To our knowledge, synthetic ligands for the $\mathrm{HCA}_{1}$ receptor have only been reported in the patent literature, which is beyond the scope of this review. Last but not least, antagonists have not been disclosed for any of the HCA receptors, which is currently hampering a full pharmacological characterization of these receptors.

\section{A. Structure-Activity Relationships for the $\mathrm{HCA}_{2}$ Receptor}

1. Nicotinic Acid-Like Compounds. Lorenzen et al. (2001) observed that nicotinic acid increases $\left[{ }^{35} \mathrm{~S}\right] \mathrm{GTP} \gamma \mathrm{S}$ 
TABLE 2

$E C_{50}$ and $K_{\mathrm{i}}$ values of nicotinic acid and related compounds

\begin{tabular}{|c|c|c|c|c|c|c|}
\hline \multirow{3}{*}{ Compound } & \multicolumn{3}{|r|}{ Rat $^{a}$} & \multicolumn{3}{|c|}{ Human $^{b}$} \\
\hline & \multicolumn{2}{|c|}{$\underset{\left(\mathrm{EC}_{50}\right)}{\mathrm{GTP} \gamma \mathrm{S}} \underset{\mathrm{Binding}}{\mathrm{B}}$} & \multirow{2}{*}{$\frac{\left[{ }^{3} \mathrm{H}\right] \text { Nicotinic Acid Binding Assay }\left(K_{\mathrm{i}}\right)}{\text { Spleen }}$} & \multirow{2}{*}{$\frac{\text { GTP } \gamma \text { S Binding Assay }\left(\mathrm{EC}_{50}\right)}{\text { HCA2 (Cloned) }}$} & \multicolumn{2}{|c|}{$\begin{array}{c}{\left[{ }^{3} \mathrm{H}\right] \text { Nicotinic Acid Binding }} \\
\text { Assay }\left(K_{\mathrm{i}}\right)\end{array}$} \\
\hline & Adipocytes & Spleen & & & HCA2 (Cloned) & Adipocytes \\
\hline & & & $\mu M$ & & & \\
\hline Nicotinic acid & 1.4 & 0.70 & 0.033 & 0.25 & 0.081 & 0.079 \\
\hline Acifran & N.D. & N.D. & N.D. & 2.1 & 1.1 & 0.83 \\
\hline Acipimox & 10 & 6.6 & 0.31 & 6.0 & 5.1 & 4.3 \\
\hline 3-Pyridine-acetic acid & 16 & 17 & 0.40 & 5.5 & 0.54 & 0.55 \\
\hline Pyridazine-4-COOH & 3.8 & 3.1 & 0.12 & N.D. & N.D. & N.D. \\
\hline Pyrazine-2-COOH & 26 & 22 & 0.76 & N.D. & N.D. & N.D. \\
\hline 5-Me-nicotinic acid & 30 & 30 & 0.72 & 8.7 & 4.12 & 3.68 \\
\hline 5-Me-pyrazine-2-COOH & 52 & 15 & 0.65 & N.D. & N.D. & N.D. \\
\hline 6-Me-nicotinic acid & 73 & 54 & 1.7 & N.D. & N.D. & N.D. \\
\hline Nicotinic acid-1-oxide & 80 & 74 & 3.2 & N.D. & N.D. & N.D. \\
\hline 2-OH-nicotinic acid & 132 & N.D. & N.D. & N.D. & N.D. & N.D. \\
\hline Furan-3-COOH & 142 & N.D. & N.D. & N.D. & N.D. & N.D. \\
\hline Nicotinamide & $>1000$ & $>1000$ & N.D. & $>1000$ & 92 & 75 \\
\hline
\end{tabular}

N.D., not determined.

${ }^{a}$ Lorenzen et al. (2001)

${ }^{b}$ Wise et al. (2003).

binding in rat epididymal adipocyte membranes in a concentration-dependent way. This provided a convenient assay format, with an $\mathrm{EC}_{50}$ value for nicotinic acid $(1.4 \mu \mathrm{M})$ that was in good agreement with the values found in earlier GTPase activation and adenylyl cyclase inhibition studies (Aktories et al., 1980a). A good window in the same assay format of $\left[{ }^{35} \mathrm{~S}\right] \mathrm{GTP} \gamma \mathrm{S}$ binding was also observed in rat spleen membranes $\left(\mathrm{EC}_{50}=0.70\right.$ $\mu \mathrm{M})$. No increase in binding was detectable in membranes from forebrain, liver, kidney, testis, heart, or lung. In a saturation radioligand binding assay with $\left[{ }^{3} \mathrm{H}\right]$ nicotinic acid, high affinity was also found in the same two tissues of rat epididymal adipocyte membranes $\left(K_{\mathrm{d}}=0.044 \mu \mathrm{M}\right)$ and rat spleen membranes $\left(K_{\mathrm{d}}=0.023 \mu \mathrm{M}\right)$. The latter, more readily available tissue was used for radioligand displacement studies. Nicotinic acid competitively displaced $\left[{ }^{3} \mathrm{H}\right]$ nicotinic acid from its binding sites $\left(K_{\mathrm{i}}=0.033 \mu \mathrm{M}\right)$. The same two assays were used by Wise et al. (2003), but now on the cloned human $\mathrm{HCA}_{2}$ receptor and on human adipocytes. Similar potency and affinity values were found for nicotinic acid, suggesting that there are no huge species differences between rat and man for nicotinic acid itself. Two other marketed products, acifran and acipimox,<smiles>O=C(O)c1cccnc1</smiles>

nicotinic acid<smiles>O=C(O)c1ccnnc1</smiles>
pyridazine-4-CA<smiles>CC1(c2ccccc2)OC(C(=O)O)=CC1=O</smiles><smiles>Cc1cnc(C(=O)O)c[n+]1[O-]</smiles><smiles>O=C(O)Cc1cccnc1</smiles>

3-pyridine-acetic acid<smiles>Cc1ccc(C(=O)O)cn1</smiles>

6-Me-nicotinic acid<smiles>O=C(O)c1cnccn1</smiles>

pyrazine-2-CA<smiles>Cc1cncc(C(=O)O)c1</smiles>

5-Me-nicotinic acid<smiles>Cc1cnc(C(=O)O)cn1</smiles>

5-Me-2-pyrazine-2-CA<smiles>CCOCCOCCOCCOCCO</smiles><smiles>NC(=O)c1cccnc1</smiles><smiles>O=C(O)c1cccnc1O</smiles>

2-OH-nicotinic acid

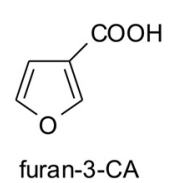

nicotinamide

Fig. 3. Chemical structures of nicotinic acid and related compounds (biological activities are in Table 1). CA, carboxylic acid. *, chiral center. 
were also tested. Acifran, on the human receptor, was $\sim 10$-fold less potent than nicotinic acid, as was acipimox on the rat receptor. Acipimox was less active on the human receptor. Changing the distance between heterocyclic core and carboxylic moiety, as in 3-pyridine-acetic acid, was not well tolerated, with a reduction in potency and affinity of more than 10-fold in both species. Modifying the heterocyclic core, either by substitution of the pyridine ring or by introduction of other heterocyclic structures, led to overall reduced activity. Best tolerated was pyridazine-4-carboxylic acid, being $\sim 5$-fold less active than nicotinic acid, whereas the simple substitution pattern in 6-methylnicotinic acid rendered the compound 50-fold less active. It is noteworthy that all active compounds in Table 2 were full agonists, in that they stimulated $\left[{ }^{35} \mathrm{~S}\right] \mathrm{GTP} \gamma \mathrm{S}$ binding to the same extent as nicotinic acid. Nicotinamide was inactive, however, suggesting that the carboxylic acid group as a negatively charged moiety is essential for activity. Gharbaoui et al. (2007) provided further variations to the theme of different heterocycles, confirming that changing the heterocycle invariably led to compounds with lower, if not negligible, potency than nicotinic acid.

2. Pyrazoles. One compound, pyrazole-3-carboxylic acid (Table 3, R1 = R2 = H), was a high-efficacy partial agonist in the rat $\left[{ }^{35} \mathrm{~S}\right] \mathrm{GTP} \gamma \mathrm{S}$ binding assay (relative intrinsic activity of $85 \%$ ) with submicromolar affinity $\left(K_{\mathrm{i}}=0.59 \mu \mathrm{M}\right)$ in the rat spleen radioligand binding assay (Lorenzen et al., 2001). This finding was taken as the starting point for a synthetic program, both in academia and industry. Partial agonists may display tissue selectivity on the basis of differences in receptor expression in different tissues. This was thought to be potentially beneficial in the case of the $\mathrm{HCA}_{2}$ receptor, as the side effect of flushing might be separated from the desired action in dyslipidemia. In the 1980s, Seki et al. (1984) had reported on substituted alkylpyrazoles as hypolipidemic agents; logically, Lorenzen et al. (2001) hypothesized that such compounds might act via the $\mathrm{HCA}_{2}$ receptor. Van Herk et al. (2003) prepared two series of alkyl- and benzyl-substituted pyrazole-3-carboxylic acid derivatives (Table 3). Partial agonism was maintained throughout the series, and some compounds had affinity values in the same range as nicotinic acid. This was particularly true for the propyl- and butylsubstituted derivatives as well as the 3-carbon atom ring-closed compound, with $K_{\mathrm{i}}$ values of $0.14,0.072$, and $0.16 \mu \mathrm{M}$, respectively, and relative intrinsic activities of 70,81 , and $56 \%$ in rat tissue. The R1 $=3$-chlorobenzyl derivative had quite acceptable affinity $\left(K_{\mathrm{i}}=0.50 \mu \mathrm{M}\right)$, modest potency in the $\left[{ }^{35} \mathrm{~S}\right] \mathrm{GTP} \gamma \mathrm{S}$ binding assay, and a relative intrinsic activity of $39 \%$. A more extended series of pyrazoles, along the same vein of either alkyl or benzyl substitution, was disclosed by Gharbaoui et al. (2007), corroborating the findings by Van Herk et al. (2003). The authors identified the 3-fluorobenzyl R1substituted pyrazole as slightly more active than the 3-chlorobenzyl derivative in a cAMP assay. Introduction of a fluoro substituent on position R2 (Table 3) was tolerated when in combination with an alkyl substituent on R1 (Skinner et al., 2007b). In that same publication, it was shown that the carboxylic acid could not easily be replaced by a similarly acidic tetrazole moiety, because most pairs differed 1 to 2 log units (or even more) in activity. Later, Semple et al. (2008) reported on one particular exception, in which the carboxylic acid/tetrazole switch yielded a partial agonist with substantial activity on the cloned human and mouse receptors in a cAMP assay. In mice, this compound [3-(1H-tetrazol-5-yl)-1,4,5,6tetrahydrocyclopentapyrazole (MK-0354)] (Fig. 4a) was as active as nicotinic acid in reducing the amount of plasma free fatty acids in vivo and had quite favorable pharmacokinetic properties, but did not cause vasodilation in the mouse ear, a surrogate marker for flushing. This differential behavior might indeed be due to the partial agonistic nature of the compound, although other expla-

TABLE 3

Affinities ( $K_{\mathrm{i}}$ values in radioligand displacement study), potencies $\left(E C_{50}\right.$ values in $\left.{ }^{35} \mathrm{~S}\right] G T P \gamma \mathrm{S}$ binding assay), and relative intrinsic activities (RIA; $\left[{ }^{35} \mathrm{~S}\right] G T P \gamma \mathrm{S}$ binding assay) of pyrazole-derived partial agonists for the rat nicotinic acid receptor

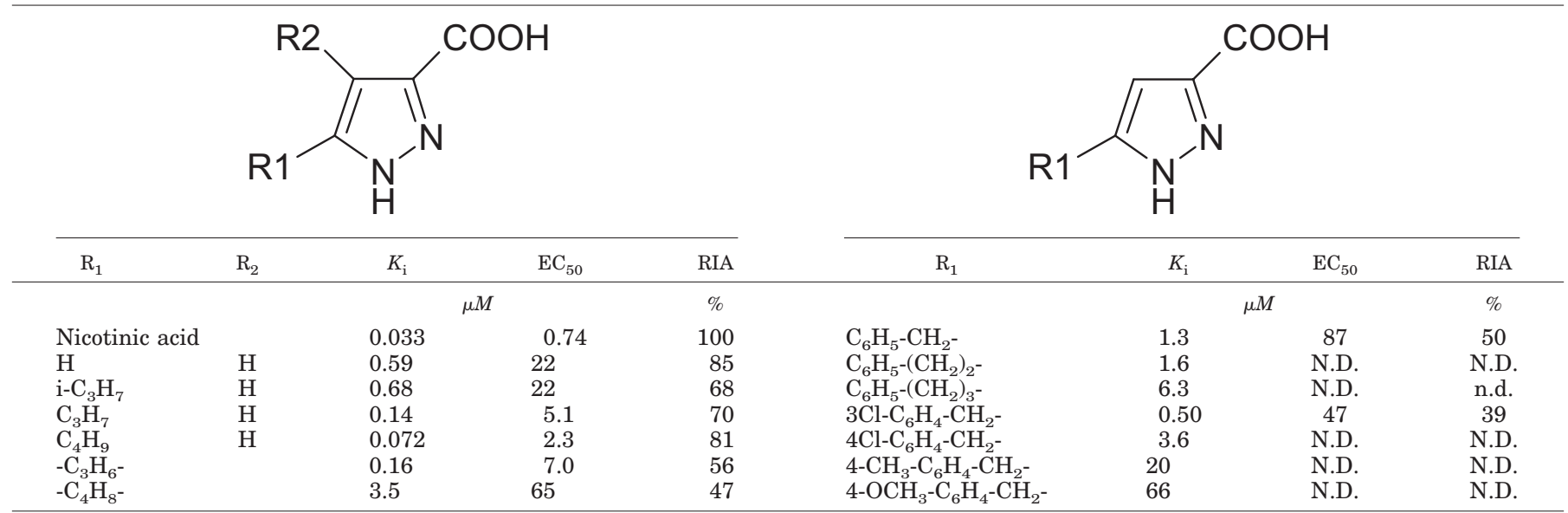

N.D., not determined. 

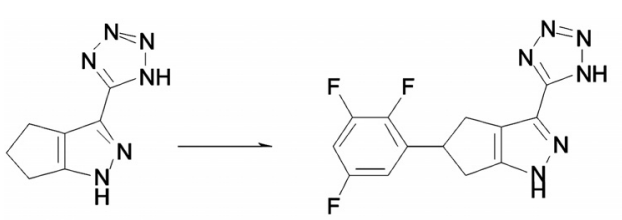

b Imbriglio et al, 2009

a MK-0354

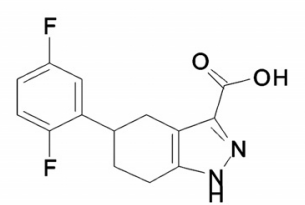

c Schmidt etal, 2009

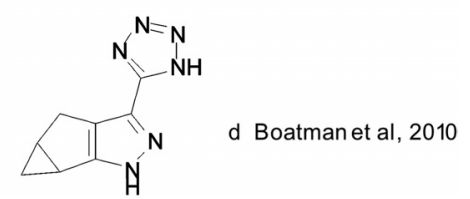

FIG. 4. Chemical structures of bicyclic pyrazole MK-0354, a highly selective partial agonist for the $\mathrm{HCA}_{2}$ receptor, and two later follow-up compounds.

nations such as biased, ligand-directed signaling may be equally feasible (Richman et al., 2007; Walters et al., 2009). MK-0354 appeared very selective, in that it did not show activity in a panel of more than 120 other proteins, including the human ether-a-go-go-related gene channel. Imbriglio et al. (2009) extended on the scaffold of MK-0354 by introducing fluorinated phenyl substituents, the 2,3,5-trifluoro variant of which (Fig. 4 b) was 2 - to 3 -fold more potent than nicotinic acid in vitro. It displayed an acceptable pharmacokinetic profile in vivo and, like MK-0354, caused no vasodilation in the mouse ear. Similar derivatives, now with a carboxylic acid function, were reported by Schmidt et al. (2009) and Imbriglio et al. (2010). One typical racemate example (Fig. 4c) and its most active enantiomer were as active as nicotinic acid in both the $\left[{ }^{3} \mathrm{H}\right]$ nicotinic acid and $\left[{ }^{35} \mathrm{~S}\right] \mathrm{GTP} \gamma \mathrm{S}$ binding assays. Boatman et al. (2008) (Fig. $4 d$ ) reported a further derivatization of MK-0354 with a cyclopropane extension.

3. Acifran Analogs. Acifran (Fig. 3) was developed in the early 1980s as a lipid-lowering agent, but structureactivity relationships were not reported. Mahboubi et al. (2006) synthesized and evaluated a small number of acifran analogs to study phosphorylation of extracellular signal-regulated kinase (ERK) 1/ERK2 in CHO cells expressing the human $\mathrm{HCA}_{2}$ receptor and to explore the triglyceride-lowering potential in fructose-fed rats. First, they identified the $S$-enantiomer of acifran as the active principle. Second, the introduction of a para-fluor substituent on the phenyl ring (Fig. 5a) preserved activity in the in vivo animal model, whereas other modifications were not allowed. Third, there was little selectivity with respect to the $\mathrm{HCA}_{3}$ receptor. A further, more extensive study was performed by Jung et al. (2007). Other substituents on the phenyl ring were tried; a 3-chloro (Fig. 5b) or -bromo substituent yielded slightly higher potency than acifran in a cAMP assay of the human
$\mathrm{HCA}_{2}$ receptor, as was the case for the introduction of a similarly substituted thiophene moiety instead of phenyl (Fig. 5c). Again, little selectivity, if any, was observed with respect to the human $\mathrm{HCA}_{3}$ receptor. Some of the analogs were resolved into their individual stereoisomers, showing that the $(+)$-isomer was invariably the biologically active principle.

4. Anthranilic Acid Derivatives. Anthranilic acid derivatives emerged from high-throughput screening campaigns at a number of companies. Merck has been most prolific in bringing these results into the peer-reviewed public domain. Shen et al. (2007a) reported on the optimization of an early hit (Fig. 6a) with an $\mathrm{EC}_{50}$ value of $6 \mu \mathrm{M}$ in the $\left[{ }^{35} \mathrm{~S}\right] \mathrm{GTP} \gamma \mathrm{S}$ binding assay, focusing on pharmacokinetic aspects, including the so-called serum shift. Although not addressed in all publications, the anthranilic acid derivatives, unlike the pyrazoles discussed above (Schmidt et al., 2009), seem to be prone to high plasma protein binding with a strong negative impact on the in vivo activity of the molecules. This was simulated by measuring the apparent affinities in the $\left[{ }^{3} \mathrm{H}\right]$ nicotinic acid binding assay in the absence and presence of $4 \%$ human serum. Serum shifts $\left(\mathrm{IC}_{50+} / \mathrm{IC}_{50-}\right)$ of 1000-fold or more seemed to be were typical for some of the anthranilic acid derivatives. A typical example is the biphenyl compound (Fig. 6b) with high affinity in the $\left[{ }^{3} \mathrm{H}\right]$ nicotinic acid binding assay in the absence of serum $\left(\mathrm{IC}_{50}=4 \mathrm{nM}\right)$ but with a serum shift of 8000 . Changing one of the phenyl groups to a heterocyclic moiety as in Fig. $6 \mathrm{c}$ improved this profile $\left(\mathrm{IC}_{50}=10 \mathrm{nM}\right.$; serum shift $=40$ ). This compound was tested in vivo, showing a favorable profile of a strong reduction of FFA levels in mice after oral dosing but failing to induce vasodilation in the mouse ear as a measure for the flushing side effect. The introduction of a piperazine ring as a linker between the aromatic fragments within the molecules yielded a series of urea analogs as in Fig. 6d (Shen et al., $2007 \mathrm{~b}$ ). This compound had an $\mathrm{IC}_{50}$ value of $140 \mathrm{nM}$ in the $\left[{ }^{3} \mathrm{H}\right]$ nicotinic acid binding assay and an $\mathrm{EC}_{50}$ value of $470 \mathrm{nM}$ in the $\left[{ }^{35} \mathrm{~S}\right] \mathrm{GTP} \gamma \mathrm{S}$ binding assay, displaying high-efficacy partial agonism (83\% of the maximal nicotinic acid response). Its serum shift was not reported. A similar derivative without the hydroxyl group on the quinoxaline moiety was tested in vivo. After intraperitoneal administration, it reduced free fatty acid levels in mice at least as efficaciously as nicotinic acid and did not induce any vasodilation. Building further on the bicyclic quinoxaline moiety, the Merck researchers developed tricyclic derivatives as well (Shen et al., 2009). A typical example (Fig. 6e) was tested in vivo in rats rather than

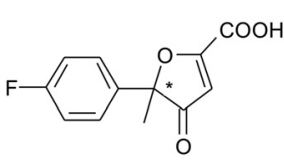

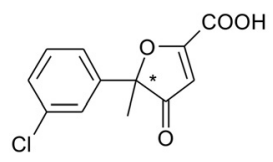

b

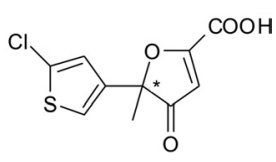

c
FIG. 5. Novel acifran analogs. *, chiral center. 
a<smiles>COc1ccc(OCC(=O)Nc2ccccc2C(=O)O)cc1</smiles>

b<smiles>O=C(CCc1ccc(-c2ccc(O)cc2Cl)cc1)Nc1ccccc1C(=O)O</smiles><smiles>O=C(CCc1nc(-c2ccc(O)cc2)no1)Nc1ccccc1C(=O)O</smiles>

d

e<smiles>CC=CC</smiles><smiles>CCCOCCc1cnn2c1CCc1cc(O)ccc1-n1ncc(CCC(=O)Nc3ccccc3C(=O)O)c1CC2</smiles>

g<smiles>CC(C)(Cc1nc(-c2ccc(O)cn2)no1)C(=O)NC1=C(C(=O)O)CCCC1</smiles>

$\mathrm{h}$<smiles>O=C(CCc1cnn(-c2ccc(O)cn2)c1)NC1=C(C(=O)O)CC(c2cc(F)cc(F)c2)CC1</smiles>

FIG. 6. Anthranilic acid derivatives and related compounds as highaffinity $\mathrm{HCA}_{2}$ receptor full agonists.

mice. Although not endowed with optimal pharmacodynamic and pharmacokinetic properties, the compound reduced free fatty acid levels as well as nicotinic acid, but its effect was longer lasting. Vasodilation in the rat ear was less than with nicotinic acid, yielding a therapeutic index (defined as $\mathrm{EC}_{50 \text {, vasodilation }} / \mathrm{EC}_{50 \text {, free fatty-acid suppression }}$ ) of 8 compared with 1 for nicotinic acid. In that study, it was also demonstrated that partial hydrogenation of the anthranilic acid phenyl ring yielded compounds that retained activity on the $\mathrm{HCA}_{2}$ receptor. This finding was more elaborately explored in another article from the Merck group (Raghavan et al., 2008). The tetrahydro analog (Fig. 6f) had $2 \mathrm{nM}$ affinity in the $\left[{ }^{3} \mathrm{H}\right]$ nicotinic acid binding assay, an $\mathrm{EC}_{50}$ value of $18 \mathrm{nM}$ in the $\left[{ }^{35} \mathrm{~S}\right] \mathrm{GTP} \gamma \mathrm{S}$ binding assay, and very acceptable pharmacokinetics in mice, whereas a value for the serum shift and in vivo efficacy data were not presented. The authors concluded that the tetrahydro variants of anthranilic acid derivatives might fare better than the parent molecules because they seemed to yield improved oral bioavailability and better cytochrome P450 profiles. A recent publication (Shen et al., 2010) describes the discovery of MK-6892 (Fig. 6g), which resulted in a preclinical candidate from the Merck anthranilic acid effort. It was also found (Ding et al., 2010; Schmidt et al., 2010) that the cyclohexene ring system in such compounds can be further substituted (e.g., Fig. 6h).

5. Fumaric and Other Acids and Their Esters. A mixture of fumaric acid esters is on the market in Germany for the treatment of psoriasis. It has recently been shown that both the monomethyl (MMF) and monoethyl (MEF) esters of fumaric acid (Fig. 7), but not fumaric acid itself, have micromolar affinity for the $\mathrm{HCA}_{2}$ receptor (Tang et al., 2008). MMF induced a concentrationdependent $\mathrm{Ca}^{2+}$ signal in transfected cells with an $\mathrm{EC}_{50}$ value of $9.4 \mu \mathrm{M}$ (nicotinic acid, $2.0 \mu \mathrm{M}$ ). MEF was approximately 3-fold less potent than MMF with an $\mathrm{EC}_{50}$ value of $26 \mu \mathrm{M}$, whereas dimethylfumarate was inactive. In a $\left[{ }^{3} \mathrm{H}\right]$ nicotinic acid radioligand displacement assay, somewhat lower $K_{\mathrm{i}}$ values were obtained: for MMF, $0.98 \mu \mathrm{M}$; for MEF, 1.3 $\mu \mathrm{M}$. A number of "simple" acids were tested by Ren et al. (2009) in several HCA2 receptor assay formats. The two most potent compounds were trans-cinnamic acid and para-coumaric acid (Fig. 7), with $\mathrm{IC}_{50}$ values in a $\left[{ }^{3} \mathrm{H}\right]$ nicotinic acid binding assay of 36 and $58 \mu \mathrm{M}$, respectively (nicotinic acid, $0.1 \mu \mathrm{M}$ ). In the $\left[{ }^{35} \mathrm{~S}\right] \mathrm{GTP} \gamma \mathrm{S}$ binding assay both compounds were somewhat less active, with $\mathrm{EC}_{50}$ values of 240 and 310 $\mu \mathrm{M}$, respectively. It is noteworthy that in a similar assay on the $\mathrm{HCA}_{3}$ receptor trans-cinnamic acid was also active $\left(\mathrm{EC}_{50}, 180 \mu \mathrm{M}\right)$, whereas para-coumaric acid was not. Oral administration of trans-cinnamic acid to wildtype mice led to a significant reduction in plasma free fatty acid levels, whereas the compound was without effect in $\mathrm{HCA}_{2}$ receptor $\mathrm{KO}$ animals.

6. Pyridopyrimidinones. Peters et al. (2010) reported on a different and quite intriguing scaffold from which $\mathrm{HCA}_{2}$ receptor agonists were derived. The pyridopyrimidi- 


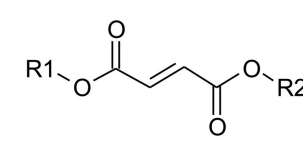

fumaric acid esters

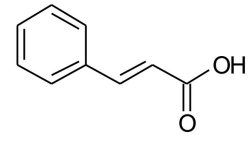

trans-cinnamic acid

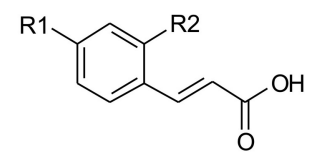

$\mathrm{R} 1=\mathrm{OH}, \mathrm{R} 2=\mathrm{H}$ : para-coumaric acid $\mathrm{R} 1=\mathrm{H}, \mathrm{R} 2=\mathrm{OH}$ : ortho-coumaric acid

$\mathrm{R} 1=\mathrm{H}, \mathrm{R} 2=\mathrm{Me}:$ MMF

$\mathrm{R} 1=\mathrm{H}, \mathrm{R} 2=\mathrm{Et}: \mathrm{MEF}$

$\mathrm{R} 1=\mathrm{R} 2=\mathrm{Me}, \mathrm{DMF}(\mathrm{BG}-12)$

FIG. 7. Fumaric acid esters and aromatic acids as agonists for the $\mathrm{HCA}_{2}$ and $\mathrm{HCA}_{3}$ receptor.

nones (Fig. 8) can be regarded as derivatives of nicotinamide (Fig. 3), a compound shown to be inactive at $\mathrm{HCA}_{2}$ receptors. Nevertheless, submicromolar affinity and potency were observed in this series, although the compounds reported so far suffer from poor pharmacokinetics.

7. Pyrazolopyrimidines as Allosteric Agonists. Shen et al. (2008) discovered another series of agonists for the $\mathrm{HCA}_{2}$ receptor with intriguing pharmacological activity. The chemical structure of the compound that was most thoroughly described is represented in Fig. 9. When tested alone it stimulated $\left[{ }^{35} \mathrm{~S}\right] \mathrm{GTP} \gamma \mathrm{S}$ binding to the human receptor to $75 \%$ of activation levels achieved with nicotinic acid, classifying it as a partial agonist. Its potency was higher than for nicotinic acid, with $\mathrm{EC}_{50}$ values of $0.12 \mu \mathrm{M}$ for the allosteric compound and 1.0 $\mu \mathrm{M}$ for nicotinic acid in this assay format. It is noteworthy that the presence of the pyrazolopyrimidine $(500$ $\mathrm{nM}-1 \mu \mathrm{M})$ shifted the concentration-effect curve of nicotinic acid significantly to the left, when measured at the level of cAMP in intact $\mathrm{CHO}$ cells expressing the human receptor, suggestive of its allosteric enhancing capability. In a radioligand binding assay, the pyrazolopyrimidine dose-dependently increased rather than displaced specific $\left[{ }^{3} \mathrm{H}\right]$ nicotinic acid binding to $400 \%$ of control levels with an $\mathrm{EC}_{50}$ value of $0.17 \mu \mathrm{M}$, yet another token of its nature as an allosteric enhancer. In general, such compounds might be used to increase the potency and/or intrinsic activity of the natural ligands for the HCA receptors. This would provide a rather physiological way of intervening with receptor function, especially if the compounds were pure allosteric enhancers without agonist activity when tested alone.

8. Patent Literature. Many companies have published patents on ligands for the $\mathrm{HCA}_{2}$ receptor. Because these publications are not peer-reviewed, we refrain from discussing them here. However, the most remarkable developments in this area have been published in four recent reviews, to which we refer the interested

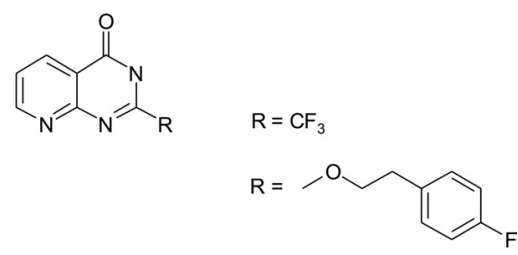

FIG. 8. Pyridopyrimidinones as a new class of selective $\mathrm{HCA}_{2}$ receptor agonists. reader: Boatman et al., 2008; Martres, 2009; Shen, 2009; Shen and Colletti, 2009.

\section{B. Structure-Activity Relationships for the $\mathrm{HCA}_{3}$ Receptor}

Because the $\mathrm{HCA}_{3}$ receptor occurs only in higher primates, the development of (rodent) animal models is hampered, which may explain the limited medicinal chemistry efforts so far. Despite the high $(>95 \%)$ homology between the two receptors, nicotinic acid is in fact very selective for the $\mathrm{HCA}_{2}$ receptor. Acifran, however, is not very selective for the two receptors, with slightly lower micromolar affinity for the $\mathrm{HCA}_{3}$ receptor (for example, Mahboubi et al., 2006; Ren et al., 2009). The most extensive structure-activity study with acifran analogs (Jung et al., 2007) showed that an ethyl rather than a methyl substituent at the chiral center in acifran (see Fig. 3) provided some (5-fold) selectivity for the $\mathrm{HCA}_{3}$ receptor, whereas all other compounds were slightly selective for the $\mathrm{HCA}_{2}$ receptor. Ren et al. (2009) identified ortho-coumaric acid (Fig. 5) as $\sim 20$-fold selective for the $\mathrm{HCA}_{3}$ receptor in a $\left[{ }^{35} \mathrm{~S}\right] \mathrm{GTP} \gamma \mathrm{S}$ binding assay. $\mathrm{EC}_{50}$ values for this compound were 70 and 1270 $\mu \mathrm{M}$ for the $\mathrm{HCA}_{3}$ and $\mathrm{HCA}_{2}$ receptors, respectively, whereas the isomer para-coumaric acid was inactive at the $\mathrm{HCA}_{3}$ receptor but not at the $\mathrm{HCA}_{2}$ receptor (see section V.A).

The first exclusive search for $\mathrm{HCA}_{3}$ receptor ligands was reported by Semple et al. (2006). In a screening campaign using a forskolin-stimulated cell line expressing the human $\mathrm{HCA}_{3}$ receptor, they discovered a benzotriazole compound (Fig. 10a) with $r=$ isopropyl as a 400 $\mathrm{nM}$ hit, reducing the cAMP production; its activity was confirmed in an antilipolysis assay with human subcutaneous adipocytes. Further exploration of the R-substituent led to a number of other potent $\mathrm{HCA}_{3}$ receptor

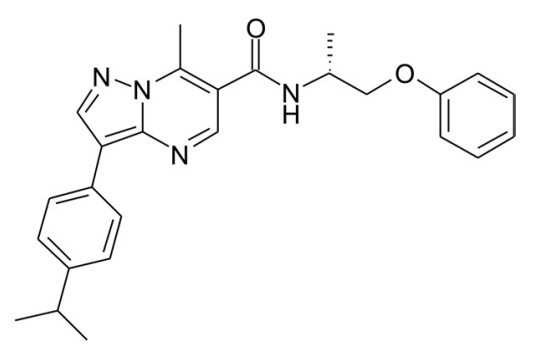

FIG. 9. Allosteric agonist for the $\mathrm{HCA}_{2}$ receptor. 
<smiles>[R]n1nnc2cc(C(=O)O)ccc21</smiles>

a benzotriazoles<smiles>[R]N([R2])c1ccc(C(=O)O)cc1[N+](=O)[O-]</smiles>

b 4-amino,3-nitrobenzoic acids<smiles>[R2]N([R2])c1ccc(C(=O)O)cn1</smiles>

c 6-aminonicotinic acids<smiles>[R]N([R2])c1cc(C(=O)O)n[nH]1</smiles>

d 5-aminopyrazole carboxylic acids

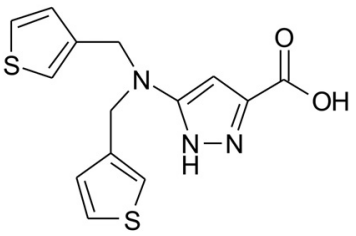

FIG. 10. Various classes of $\mathrm{HCA}_{3}$ receptor ligands.

agonists [e.g., $\mathrm{R}=2$-butyl $\left(\mathrm{EC}_{50}=330 \mathrm{nM}\right)$ ], $\mathrm{R}=$ $\mathrm{CH}\left(\mathrm{CH}_{3}\right) \mathrm{CH}_{2} \mathrm{OCH}_{3}\left(\mathrm{EC}_{50}=200 \mathrm{nM}\right)$ being the most potent compound. None of the compounds displayed any activity on the $\mathrm{HCA}_{2}$ receptor. A subtle change to $\mathrm{R}=$ propyl instead of isopropyl yielded significantly less activity $\left(\mathrm{EC}_{50}=7.4 \mu \mathrm{M}\right)$.

The same research team discovered that some 4-amino3-nitrobenzoic acids, used as intermediates in the synthesis of the benzotriazoles, also displayed significant activity at $\mathrm{HCA}_{3}$ receptors and selectivity over $\mathrm{HCA}_{2}$ receptors (Skinner et al., 2007a). A wider range of these acids, now substituted at the 4-amino group (Fig. 10b), was synthesized and tested in the cAMP whole-cell assay mentioned above. Three compounds displayed full agonist responses with $\mathrm{EC}_{50}$ values below $100 \mathrm{nM}$, the most potent $\left(R_{1}=\right.$ propyl, $\left.R_{2}=H\right)$ with an $\mathrm{EC}_{50}$ value of $30 \mathrm{nM}$. In the same publication, it was hypothesized that a pyridine ring could substitute for the nitro-aryl moiety, avoiding the nitro group as a possible toxicophore. Indeed, the resulting 6 -amino-substituted nicotinic acids (Fig. 10c) proved active as $\mathrm{HCA}_{3}$ receptor full agonists when tested in the cAMP whole-cell assay. The structure-activity relationships between the two series were very similar. Again, the $n$-propyl-substituted compound was the most active one $\left(\mathrm{EC}_{50}=51 \mathrm{nM}\right)$. Double substitution of the amino group, however, was less favored than in the 4-amino-3-nitrobenzoic acids.

The synthetic efforts were extended to the pyrazole carboxylic acids as a template for the $\mathrm{HCA}_{3}$ receptor (Skinner et al., 2009). Not surprisingly, the same substituted amino group was introduced to the pyrazole ring system (Fig. 10d). Here, double substitution to yield a tertiary amine was particularly explored, providing a typical pattern of thiophene derivatives, one of which (Fig. 10e) had high potency with an $\mathrm{EC}_{50}$ value of $3 \mathrm{nM}$ and more than 1000 -fold selectivity with respect to the $\mathrm{HCA}_{2}$ receptor. It is noteworthy that replacing -S- with -O- to yield 3 '-furanyl substitution rendered the com- pound at least 1000 -fold less active at the $\mathrm{HCA}_{3}$ receptor.

\section{Receptor Signaling and Regulation}

\section{A. G-Protein Coupling}

The sensitivity of nicotinic acid-induced effects to the action of pertussis toxin (islet-activating protein) pointed to G-proteins of the $\mathrm{G}_{\mathrm{i}} / \mathrm{G}_{\mathrm{o}}$-family as the G-proteins coupled to the nicotinic acid receptor (Aktories et al., 1983). After the identification of the $\mathrm{HCA}_{2}$ receptor as a nicotinic acid and ketone body receptor and the discovery of ligands activating $\mathrm{HCA}_{1}$ and $\mathrm{HCA}_{3}$ receptors, it has been shown in numerous models that the effects mediated by all three receptors are inhibited by pertussis toxin (Soga et al., 2003; Tunaru et al., 2003; Wise et al., 2003; Cai et al., 2008; Ge et al., 2008; Ahmed et al., 2009a; Irukayama-Tomobe et al., 2009; Liu et al., 2009). Thus, $\mathrm{HCA}_{1}, \mathrm{HCA}_{2}$, and $\mathrm{HCA}_{3}$ receptors are $\mathrm{G}_{\mathrm{i}} / \mathrm{G}_{\mathrm{o}}$-coupled receptors.

\section{B. Downstream Signaling}

Consistent with the fact that all three receptors are $\mathrm{G}_{\mathrm{i}} / \mathrm{G}_{\mathrm{o}}$-coupled, agonists of $\mathrm{HCA}_{1}, \mathrm{HCA}_{2}$, and $\mathrm{HCA}_{3}$ receptors have been shown to inhibit adenylyl cyclase activity and thereby to decrease cAMP levels in various cells after heterologous expression of the receptors as well as in primary adipocytes (Soga et al., 2003; Tunaru et al., 2003; Wise et al., 2003; Richman et al., 2007; Ahmed et al., 2009a, 2010; Liu et al., 2009). In adipocytes, a decrease in cAMP results in an antilipolytic effect because cAMP is the major intracellular regulator of lipolysis by stimulating cAMP-dependent kinase to activate lipolytic enzymes (Duncan et al., 2007). Also, in human neutrophils as well as in the human epidermoid cell line A431, activation of the $\mathrm{HCA}_{2}$ receptor has been shown to result in decreased cAMP levels (Zhou et al., 2007; Kostylina et al., 2008). Kostylina et al. (2008) 
suggested that the decrease in cAMP levels induced by activation of the $\mathrm{HCA}_{2}$ receptor in neutrophils induces apoptosis through a reduction in phosphorylation of the proapoptotic protein Bad via cAMP-dependent protein kinase.

In immune cells, activation of $\mathrm{G}_{\mathrm{i}}$ results in stimulation of phospholipase $\mathrm{C} \beta$-isoforms, most likely through the release of G-protein $\beta \gamma$-subunits (Exton, 1996). Consistent with this, $\mathrm{HCA}_{2}$ and $\mathrm{HCA}_{3}$ receptors, which are expressed in neutrophils, macrophages, and other immune cells, have been shown to mediate ligand-induced increases in free intracellular $\mathrm{Ca}^{2+}$ concentrations in a $\mathrm{G}_{\mathrm{i}} / \mathrm{G}_{\mathrm{o}}$-dependent manner (Benyó et al., 2006; Tang et al., 2006; Kostylina et al., 2008; Ahmed et al., 2009a; Irukayama-Tomobe et al., 2009). It has been suggested that the increase in intracellular $\mathrm{Ca}^{2+}$ concentrations mediated by $\mathrm{HCA}_{2}$ receptors in response to nicotinic acid results in the activation of $\mathrm{Ca}^{2+}$-sensitive phospholipase $\mathrm{A}_{2}$ and subsequent formation of prostanoids (Benyó et al., 2005, 2006; Tang et al., 2006). This would well explain the rapid formation of prostanoids such as prostaglandins $\mathrm{D}_{2}$ and $\mathrm{E}_{2}$ in response to nicotinic acid (Morrow et al., 1989; Cheng et al., 2006; Maciejewski-Lenoir et al., 2006). Alternatively, phospholipase $\mathrm{A}_{2}$ can also be phosphorylated and activated by ERK, which in turn can be activated through HCA receptors (Tunaru et al., 2003; Richman et al., 2007; Ahmed et al., 2009a; Liu et al., 2009; Walters et al., 2009). This effect is dependent on $\beta$-arrestin, and activation of ERK via the $\mathrm{HCA}_{2}$ receptor has been shown to involve the recruitment of $\beta$-arrestin to the plasma membrane (Walters et al., 2009). In addition, Walters et al. (2009) showed that upon $\mathrm{HCA}_{2}$ receptor activation, $\beta$-arrestin- 1 binds to cytosolic phospholipase $\mathrm{A}_{2}\left(\mathrm{PLA}_{2}\right)$ and activates the enzyme. This results in the release of arachidonic acid and provides an alternative mechanism for the stimulation of $\mathrm{PLA}_{2}$-dependent prostanoid formation through HCA receptors in immune cells. The $\mathrm{HCA}_{2}$ receptor-mediated activation of $\mathrm{PLA}_{2}$ and subsequent formation of prostanoids such as prostaglandins ( $P G) \mathrm{D}_{2} \mathrm{E}_{2}$ in epidermal cells is a critical mechanism underlying the nicotinic acid-induced flushing reaction (see section VII).

\section{Receptor Desensitization}

There is ample evidence that some of the effects mediated by the $\mathrm{HCA}_{2}$ receptor are subject to desensitization (Stern et al., 1991). Consistent with this, nicotinic acid-induced flushing mediated by the $\mathrm{HCA}_{2}$ receptor as well as nicotinic acid-induced increases in intracellular $\mathrm{Ca}^{2+}$ concentrations are showing desensitization within minutes (Benyó et al., 2005; Kostylina et al., 2008). However, whether these desensitization phenomena are due to effects on the receptor itself or are at the level of downstream signaling processes is not clear. For heterologously expressed $\mathrm{HCA}_{1}$ and $\mathrm{HCA}_{2}$ receptors, internalization of the receptor in response to ligand application has been described previously (Richman et al., 2007;
Liu et al., 2009; Li et al., 2010). In the case of heterologously expressed $\mathrm{HCA}_{2}$ receptor, internalization is dependent on the type of ligand. The full agonist nicotinic acid induced internalization, whereas a partial agonist (which, unlike nicotinic acid, did not induce ERK phosphorylation) had no effect (Richman et al., 2007). Internalization of heterologously expressed $\mathrm{HCA}_{2}$ activated by nicotinic acid was shown to occur in a manner dependent on G-protein-coupled receptor kinase 2 (GRK2) and arrestin 3, whereas the recycling of the internalized receptor was independent of endosomal acidification $(\mathrm{Li}$ et al., 2010).

\section{Biological Roles}

\section{A. $H C A_{1}$}

Because the $\mathrm{HCA}_{1}$ receptor is almost exclusively expressed in adipocytes and because it mediates lactateinduced, $\mathrm{G}_{\mathrm{i}}$-dependent inhibition of adenylyl cyclase activity, the obvious biological role of the $\mathrm{HCA}_{1}$ receptor is the inhibitory regulation of adipocyte lipolysis (Cai et al., 2008; Liu et al., 2009; Ahmed et al., 2010). The classic situation leading to elevated plasma lactate levels is intensive exercise during which the anaerobic degradation of carbohydrates to lactate is the major energyproviding pathway (Brooks and Mercier, 1994). It is plausible that under conditions of intensive exercise, when free fatty acid oxidation is strongly reduced, lactate would exert an inhibitory effect on the fatty acid release from adipocytes (Issekutz and Miller, 1962). Although lactate can inhibit lipolysis(Fredholm, 1971; Boyd et al., 1974; Cai et al., 2008; Liu et al., 2009; Ahmed et al., 2010), there is no proof for this concept, which has been rather controversial (Trudeau et al., 1999). When wild-type and $\mathrm{HCA}_{1}$ receptor-deficient mice were trained to exercise at an intensity that resulted in plasma lactate levels sufficient to activate the $\mathrm{HCA}_{1}$ receptor, no difference between the plasma concentrations of free fatty acids could be observed between wild-type and $\mathrm{HCA}_{1}$ receptor-deficient mice (Ahmed et al., 2010). Therefore, lactate and its receptor do not seem to critically contribute to the regulation of lipolysis under conditions of intensive exercise.

Adipocytes are another source of lactate, in that they can convert more than $50 \%$ of the metabolized glucose to lactate, a process stimulated by insulin and glucose uptake (DiGirolamo et al., 1992). The liver takes up the lactate released from adipocytes and uses it for gluconeogenesis and glycogen synthesis. Because insulin-induced glucose uptake results in a severalfold increase in extracellular lactate levels in adipose tissue (Jansson et al., 1994; Qvisth et al., 2007; Ahmed et al., 2010), the hypothesis was formulated that lactate, acting through the $\mathrm{HCA}_{1}$ receptor, contributes to the inhibition of lipolysis induced by insulin. In fact, studies in $\mathrm{HCA}_{1}$ receptor-deficient mice and adipocytes clearly showed that insulin-induced inhibition of lipolysis and insulin-in- 
duced decrease in adipocyte cAMP were strongly reduced in the absence of $\mathrm{HCA}_{1}$ (Ahmed et al., 2010). Thus, lactate acting through $\mathrm{HCA}_{1}$ functions in an autocrine and paracrine fashion to mediate insulin-induced antilipolytic effects (Fig. 11). Mice lacking $\mathrm{HCA}_{1}$ show a reduced weight gain under high fat diet, indicating that this mechanism may contribute to the increase in body weight under hypercaloric diet. Thus, blockade of the $\mathrm{HCA}_{1}$ receptor may be a strategy for treating obese patients.

\section{B. $\mathrm{HCA}_{2}$}

Although the $\mathrm{HCA}_{2}$ receptor is an important target for the drug nicotinic acid, its biological role is instead related to the ketone body 3-hydroxy-butyrate, which activates the receptor with an $\mathrm{EC}_{50}$ of approximately 700 $\mu \mathrm{M}$ (Taggart et al., 2005). Under normal conditions, 3-hydroxy-butyrate plasma levels are 50 to $400 \mu \mathrm{M}$, but they increase after an overnight fast to 1 to $2 \mathrm{mM}$ and reach 6 to $8 \mathrm{mM}$ during prolonged starvation (Owen et al., 1969). Because the formation of 3-hydroxy-butyrate in the liver depends on the delivery of free fatty acids induced by lipolysis in adipocytes, the activation of the $\mathrm{HCA}_{2}$ receptor by 3-hydroxy-butyrate at millimolar concentrations and the subsequent antilipolytic effect represent a classic negative feedback mechanism that controls the lipolytic rate during starvation (Senior and Loridan, 1968) (Fig. 11). In isolated adipocytes from wild-type mice 3-hydroxy-butyrate inhibits lipolysis, an effect that is not seen in adipocytes from $\mathrm{HCA}_{2}$ receptordeficient mice (Taggart et al., 2005), further supporting the notion that the $\mathrm{HCA}_{2}$ receptor functions as a metabolic sensor that regulates lipolytic activity during starvation to avoid excessive triglyceride degradation.
The $\mathrm{HCA}_{2}$ receptor agonist nicotinic acid has been used for decades as an antidyslipidemic drug to prevent and treat atherosclerosis (Meyers et al., 2004; Carlson, 2005). Its therapeutic potential is well established (see section VIII). Several mechanisms have been proposed to account for the antiatherosclerotic effects of nicotinic acid (Gille et al., 2008; Kamanna and Kashyap, 2008; Digby et al., 2009). Nicotinic acid reduces low-density lipoprotein (LDL) cholesterol, triglyceride, and lipoprotein(a) plasma levels and simultaneously increases levels of HDL cholesterol (Carlson, 2005). Among the mechanisms that have been proposed to account for the antidyslipidemic properties of nicotinic acid is the activation of $\mathrm{HCA}_{2}$ receptors expressed on adipocytes. The antilipolytic effect of $\mathrm{HCA}_{2}$ receptor activation on adipocytes results in a decreased release of free fatty acids from fat cells. This in return reduces the supply of free fatty acids to the liver, leading to a reduced synthesis of triglycerides and very-low-density lipoprotein as well as to a subsequent drop in LDL cholesterol levels (Carlson, 1963). How nicotinic acid increases HDL cholesterol levels is less clear. The decrease in triglyceride content of apolipoprotein B-containing lipoproteins may result in a decreased exchange of triglycerides for cholesteryl esters from HDL particles mediated by the cholesterol transfer protein, eventually leading to increased HDL cholesterol levels (Kontush and Chapman, 2006; Offermanns, 2006; Joy and Hegele, 2008). This mechanism is supported by the observation that HDL-cholesterol elevation in response to nicotinic acid depends on the presence of cholesterol transfer protein (Hernandez et al., 2007; van der Hoorn et al., 2008). Whether the $\mathrm{HCA}_{2}$ receptor also mediates the increase in HDL-cholesterol levels in response to nicotinic acid, however, remains unclear
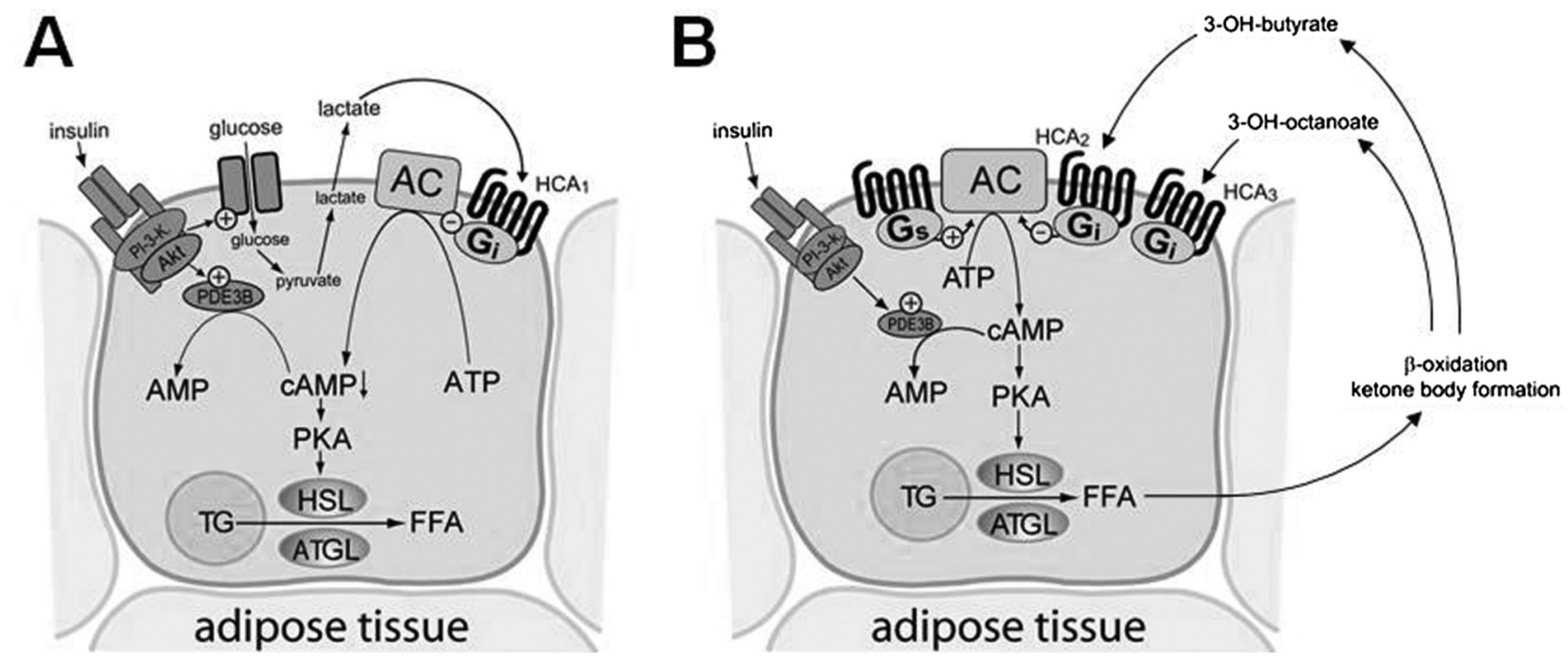

FIG. 11. Functions of the recently deorphanized receptors $\mathrm{HCA}_{1}, \mathrm{HCA}_{2}$, and $\mathrm{HCA}_{3}$. The lactate receptor $\mathrm{HCA}_{1}$ mediates the short-term anabolic

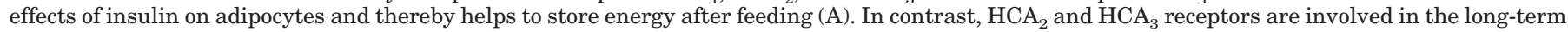

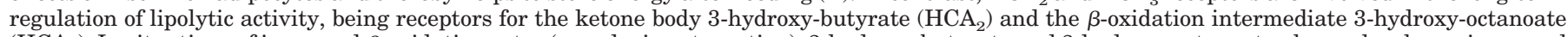

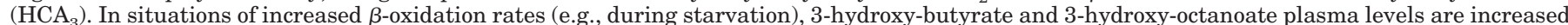

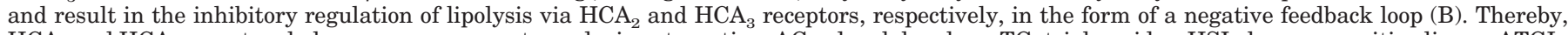

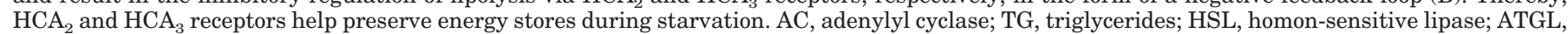
adipocyte triglyceride lipase; FFA, free fatty acids; PKA, cAMP-regulated protein kinase. 
(Bodor and Offermanns, 2008; Kamanna and Kashyap, 2008). Because mouse lipoprotein metabolism is considerably different from that of humans, genetic mouse models are not helpful in analyzing this question. Selective antagonists of the $\mathrm{HCA}_{2}$ receptor tested in appropriate models may eventually be helpful in answering this question.

The physiological role of the $\mathrm{HCA}_{2}$ receptor in immune cells, such as macrophages or neutrophils, that express the receptor remains currently unclear. Given that plasma levels of 3-OH-butyrate, the endogenous ligand of $\mathrm{HCA}_{2}$, are highly elevated under starving conditions, one may speculate that the $\mathrm{HCA}_{2}$ receptor expressed on immune cells mediates anti-inflammatory effects that could be advantageous under conditions of starvation. In this respect, it is interesting to know that $\mathrm{HCA}_{2}$ expression in macrophages is up-regulated by various cytokines and activators of innate immunity (see section IV).

There is good evidence that expression of the $\mathrm{HCA}_{2}$ receptor in epidermal Langerhans cells and keratinocytes is responsible for one of the major unwanted effects of nicotinic acid, the flushing reaction. Flushing results from a cutaneous vasodilation associated with a sensation of tingling and burning that causes many patients to discontinue nicotinic acid therapy (Benyó et al., 2005, 2006; Maciejewski-Lenoir et al., 2006; Gille et al., 2008; Kamanna et al., 2009). The induction of a flush reaction by nicotinic acid or the antipsoriatic drug monomethyl fumarate is mediated by $\mathrm{HCA}_{2}$ and shows a biphasic increase in dermal blood flow (Hanson et al., 2010). The first phase is induced via activation of $\mathrm{HCA}_{2}$ on Langerhans cells, and $\mathrm{HCA}_{2}$ on keratinocytes is responsible for the late phase of the response. Whereas Langerhans cell-mediated flushing involves cyclooxygenase-1, $\mathrm{PGD}_{2}$, and $\mathrm{PGE}_{2}$, keratinocyte-mediated late-phase flushing involves cyclooxygenase-2 and $\mathrm{PGE}_{2}$ (Benyó et al., 2005; Cheng et al., 2006; Paolini et al., 2008; Hanson et al., 2010). The expression of $\mathrm{HCA}_{2}$ in various cells of the epidermis and the marked epidermal and dermal effects resulting from the activation of $\mathrm{HCA}_{2}$ has raised the question whether this receptor system has any physiological or pathophysiological role in the skin, besides its pharmacological function. $\mathrm{HCA}_{2}$-mediated prostanoid formation in Langerhans cells and keratinocytes, for instance, may underlie some of the many forms of skin reactions in which alterations or traumata in the epidermis result in dermal vasodilation and various dermal sensations. It will be interesting to explore in the future the potential physiological and pathophysiological role of $\mathrm{HCA}_{2}$-mediated cellular effects in the epidermis.

The $\mathrm{HCA}_{2}$ receptor has also been shown to be expressed in intestinal epithelial cells where the receptor may respond to butyrate, which is present in millimolar concentrations in the gut lumen. It has been suggested that $\mathrm{HCA}_{2}$ thereby functions as a tumor suppressor and anti-inflammatory receptor (Thangaraju et al., 2009).

\section{C. $\mathrm{HCA}_{3}$}

The biological role of the $\mathrm{HCA}_{3}$ receptor seems to be quite similar to that of the $\mathrm{HCA}_{2}$ receptor with regard to the regulation of adipocyte lipolysis. The plasma concentration of the $\beta$-oxidation intermediate 3-hydroxy-octanoate, which activates $\mathrm{HCA}_{3}$ receptors at micromolar concentrations, increases substantially under conditions of increased free fatty acid oxidation during fasting, during diabetic ketoacidosis, in various mitochondrial fatty acid $\beta$-oxidation disorders, and under the influence of a ketogenic diet (Costa et al., 1998; Jones et al., 2002; Ahmed et al., 2009a). Similar to $\mathrm{HCA}_{2}$, the $\mathrm{HCA}_{3}$ receptor mediates a negative feedback mechanism under these conditions to counterbalance prolipolytic stimuli (Ahmed et al., 2009b) (Fig. 11). The fact that the $\mathrm{HCA}_{3}$ receptor is found only in higher primates suggests that the optimal regulation of lipolytic activity under conditions of increased free fatty acid release during starvation and other extreme conditions represents an important mechanism to use the energy stored in form of triglycerides economically and to avoid a waste of energy. The advantage of having additional regulatory mechanisms under these conditions was apparently sufficient to drive the evolution of additional lipolysis-controlling receptors in higher primates. Whether $\mathrm{HCA}_{3}$ has potential biological roles outside the adipose tissue is currently not known.

\section{Therapeutic Potential of Hydroxy-carboxylic Acid Receptor Ligands}

In this paragraph the effects of HCA receptor ligands in the clinic will be briefly discussed. Not surprisingly, nicotinic acid itself has been the best studied compound in this respect, either alone or in combination with other lipid-altering drugs.

\section{A. Nicotinic Acid Alone}

Nicotinic acid has been used in clinical practice for more than half a century now, ever since Altschul et al. (1955) pioneered its use as an antidyslipidemic drug in man. This finding was followed-up by a number of further clinical studies that all established the usefulness of nicotinic acid as a "broad-spectrum" lipid-modulating drug (for a recent review, see Carlson, 2005; Guyton, 2007), albeit with predominantly dermatological side effects (flushing). In a well defined early long-term trial, nicotinic acid treatment had no effect on total mortality compared with placebo, although it showed a modest benefit in lowering the incidence of recurrent myocardial infarction (Coronary Drug Project Research Group, 1975). It is noteworthy that 9 years after conclusion of this trial, mortality in the nicotinic acid-treated patient group was a significant $11 \%$ lower than placebo (Canner et al., 1986). The authors concluded that this delayed benefit of nicotinic acid, occurring after discontinuation of the drug, may relate to the early favorable effect of nicotinic acid on reinfarction incidents and/or may be 
the result of the cholesterol-altering effect of nicotinic acid.

\section{B. Nicotinic Acid with Antiflushing Strategies}

The use of generic nicotinic acid in its crystalline form has always been associated with the common side effect of flushing, which had a strong negative impact on patient compliance. Strategies such as taking tablets during meals and/or taking acetylsalicylic acid concomitantly often render the flushing bearable; in addition, it seems to wane over time.

1. Modified Release Formulations. Formulation of nicotinic acid in slow- or extended-release forms also helps. In particular, the extended-release form has been clinically evaluated, also as monotherapy. Capuzzi et al. (1998) defined its efficacy and safety in a long-term study in over 500 patients for almost 2 years. A reduction in LDL cholesterol levels of $\leq 20 \%$ was observed with a concomitant increase of $\leq 28 \%$ in HDL cholesterol levels. Nevertheless, flushing continued to be a significant side effect in $75 \%$ of the patients.

2. Combinations with Antiflushing Drugs. Acetylsalicylic acid can be combined with nicotinic acid to reduce flushing (Oberwittler and Baccara-Dinet, 2006). The rationale is that the compound inhibits prostaglandin synthesis, including the formation of prostaglandin $\mathrm{D}_{2}$. This eicosanoid plays a major role in the genesis of the flushing syndrome in that it causes cutaneous vasodilation (see sections VI and VII). A more recent development is the addition of a selective $\mathrm{PGD}_{2}$ receptor 1 antagonist, laropiprant, to nicotinic acid therapy (Cheng et al., 2006). More than 400 patients were treated, a subpopulation of which received nicotinic acid in its extended release form in combination with various doses of laropiprant for at least 8 weeks. These patients experienced significantly less flushing than those on nicotinic acid alone. It is noteworthy that all doses of laropiprant tested were equally effective in inhibiting the flushing syndrome (Paolini et al., 2008). The data from this and a few more recent trials with similar outcomes have been summarized by McKenney et al. (2010). As a result, a fixed-dose combination formulation (1000 mg of nicotinic acid/20 mg of laropiprant) was allowed access to the market in Europe in 2008, whereas the U.S. Food and Drug Administration has asked for further studies.

\section{Nicotinic Acid in Combination with Other Lipid-Altering Drugs}

Many later clinical trials were designed to evaluate the use of nicotinic acid in combination with other lipidaltering drugs, particularly HMG-CoA reductase inhibitors ("statins"). On many occasions, a significant reduction of coronary events and mortality was observed. With statins emerging as a first-choice strategy for lipid lowering in the $1990 \mathrm{~s}$, it was only logical to examine the combined effects of nicotinic acid with one of the early HMG-CoA reductase inhibitors, simvastatin, in a dou- ble-blind trial with 160 patients with established coronary heart disease and low HDL cholesterol plasma levels observed for 3 years (Brown et al., 2001). The mean levels of LDL and HDL cholesterol were unaltered in the placebo group, but changed by -42 and $+26 \%$, respectively, in the simvastatin-plus-nicotinic acid group. This was manifested clinically by a strong reduction in the frequency of a first cardiovascular event (24 versus 3\%). Although the ideal control group receiving simvastatin alone was not tested, the reduction in cardiovascular events in patients treated with simvastatin and nicotinic acid was much larger than would have been expected from a treatment with simvastatin alone.

An important surrogate endpoint in many trials is the impact on the size of atherosclerotic lesions, which is not altered very much on statin monotherapy (Guyton, 2007). In all clinical trials, addition of nicotinic acid to statin therapy resulted in a reduced development of atherosclerotic lesions. For instance, in the ARBITER 2 study (Taylor et al., 2004), patients with coronary heart disease who were treated with statins and had low levels of HDL cholesterol received nicotinic acid as a supplementary drug regimen. The primary endpoint was the change in common carotid intima-media thickness after 1 year. After this period, compared with values at the start of the study, the thickness was significantly increased in the placebo group but unchanged in the patients treated with nicotinic acid. The overall difference in thickness progression between the nicotinic acid and placebo groups was not statistically significant, however (Taylor et al., 2004). A similar, more recent study (ARBITER6-HALTS) compared the addition of either nicotinic acid (extended release) or ezetimibe to statin monotherapy (Taylor et al., 2009). Niacin proved superior to ezetimibe on the basis of the same primary clinical endpoint of the mean common carotid intima-media thickness after 14 months of treatment. A total of 363 patients were enrolled, but after 208 patients had completed the study, it was decided to halt the trial because the use of ezetimibe led to a paradoxical increase in atherosclerosis, despite the significant (further) reduction in LDL cholesterol levels. In the nicotinic acid-plusstatin group, a significant regression of both mean and maximal carotid intima-media thickness was observed, in combination with a significant $18 \%$ increase in HDL cholesterol levels.

Two cardiovascular endpoint trials are currently under way to test whether the addition of nicotinic acid to statins has a beneficial effect on the progression of cardiovascular disease, incidence of major cardiovascular events, and cardiovascular disease-associated mortality. The Atherothrombosis Intervention in Metabolic Syndrome with low HDL/high triglycerides and Impact on Global Health Outcomes (AIM-HIGH) study compares simvastatin and extended-release nicotinic acid with simvastatin monotherapy in 3300 patients at high risk suffering from cardiovascular disease, low HDL choles- 
terol, and high triglyceride levels (http://clinicaltrials. gov/ct2/show/NCT00120289). The Heart Protection study 2: Treatment of HDL to Reduce the Incidence of Vascular Events (HPS2-THRIVE) compares simvastatin plus extended-release nicotinic acid plus the prostaglandin $D_{2}$ receptor 1 antagonist laropiprant with simvastatin monotherapy in more than 20,000 patients with coronary heart disease (http://clinicaltrials.gov/ct2/show/ NCT00461630). The results of these trials are expected to be reported between 2011 and 2013.

\section{Fumaric Acid Derivatives}

The use of fumaric acid esters for the treatment of psoriasis goes back to case reports in Germany as early as 1959 (Schweckendiek, 1959). A small randomized, double-blind, placebo-controlled study involving 39 patients showed that oral administration of a combination of fumarate esters (the monoethyl- and dimethyl ana$\operatorname{logs}$ ) led to a significant reduction of body surface affected with psoriasis with an average of $21 \%$ at the start of the study to $6.7 \%$ after 16 weeks. Almost all patients suffered from flushing and diarrhea (Nugteren-Huying et al., 1990). Prolonged use of fumaric acid esters up to 14 years did not seem to cause unacceptable or unbearable side effects, composed mostly of flushing, diarrhea, and lymphocytopenia (Hoefnagel et al., 2003). In a recent study, a retrospective analysis of close to 1000 patients treated in over 150 centers for at least 2 years yielded similar results (i.e., sustained clinical efficacy and an acceptable safety profile) (Reich et al., 2009). Among the many suggested molecular mechanisms of action, the fumarate esters have been shown to interact with the $\mathrm{HCA}_{2}$ receptor, which may in fact cause the flushing. A similar preparation (BG-12, consisting of dimethylfumarate only) was tested in a double-blind, placebo-controlled clinical phase IIb study in more than 250 patients with relapsing-remitting multiple sclerosis. Treatment with BG-12 (240 mg three times daily) significantly reduced the mean total number of new brain lesions by more than $70 \%$ compared with placebo. Again, adverse events included abdominal pain and flushing (Kappos et al., 2008). Given the expression of $\mathrm{HCA}_{2}$ receptors in various immune cells and the reported beneficial effects of fumaric acid esters, which are able to activate $\mathrm{HCA}_{2}$ receptors, it is tempting to speculate that $\mathrm{HCA}_{2}$ receptors may be interesting targets for anti-inflammatory or immunosuppressive therapeutic approaches.

\section{E. Clinical Candidates}

A partial agonist for the $\mathrm{HCA}_{2}$ receptor, MK-0354 (Fig. 4), was evaluated in both phase I and II clinical studies. The effects of single and multiple doses of MK$0354(300 \mathrm{mg}-4 \mathrm{~g})$ were evaluated in two phase I studies conducted in healthy men. In a phase II study, the effects of MK-0354 (2.5 g once daily) on lipids were recorded during 4 weeks in 66 dyslipidemic patients. In the phase I study, it was noticed that a single dose (300 $\mathrm{mg}$ ) of MK-0354 reduced free fatty acid levels comparable with a 1-g dose of extended-release nicotinic acid, which did not alter after 7 days of administration. In the phase II study, $2.5 \mathrm{~g}$ of MK-0354 produced little flushing; however, no clinically meaningful effects on lipids, especially on HDL levels, were observed (Lai et al., 2008).

\section{Conclusion}

Despite the medical relevance of $\mathrm{HCA}_{2}$ as a receptor for nicotinic acid and the development of many synthetic ligands of $\mathrm{HCA}_{2}$ and $\mathrm{HCA}_{3}$ receptors, endogenous agonists of receptors of the HCA family have only recently been identified. This is most likely because their physiological ligands do not represent classic GPCR agonists such as hormones, neurotransmitters, or other mediators but are metabolites that have traditionally not been regarded as bona fide G-protein-coupled receptor agonists. Another unusual property of endogenous HCA receptor ligands that has made their identification difficult is their relatively low potency, especially in the case of $\mathrm{HCA}_{1}$ and $\mathrm{HCA}_{2}$, with $\mathrm{EC}_{50}$ values in the millimolar range. Based on the well known pharmacological properties of nicotinic acid and the fact that all three HCA receptors are expressed in adipocytes and signal through $\mathrm{G}_{\mathrm{i}}$-type $\mathrm{G}$-proteins, there has been great interest in the development of synthetic ligands that act through HCA receptors to induce antidyslipidemic effects similar to those of nicotinic acid. Although this approach involved the generation of agonistic ligands, the analysis of $\mathrm{HCA}_{1}$-deficient animals suggests also that antagonists may have a pharmacological potential by reducing postprandial antilipolysis and reducing the weight gain under high-calorie diet. Future studies will have to clarify whether any of these strategies will be beneficial in defined groups of patients. In contrast to the $\mathrm{HCA}_{1}$ receptor, $\mathrm{HCA}_{2}$ and $\mathrm{HCA}_{3}$ receptors are also expressed in a variety of immune cells. Increasing evidence indicates that activation of $\mathrm{HCA}_{2}$ and $\mathrm{HCA}_{3}$ on immune cells may have beneficial effects on various inflammatory diseases, making both receptors attractive targets for atherosclerosis, chronic inflammatory, and autoimmune disorders. The development of selective high-affinity agonists and antagonists for these receptors will in the future help to not only better understand their physiological roles but also to further explore their potential as therapeutic targets.

\section{Acknowledgments}

This work was supported by the German Research Foundation (to S.O.) and the Dutch Top Institute Pharma [project D1-105] (to A.P.IJ.). We thank Svea Hümmer for excellent secretarial help in preparing the manuscript.

\footnotetext{
Authorship Contributions

Wrote or contributed to the writing of the manuscript: Offermanns, Colletti, Lovenberg, Semple, Wise, and IJzerman.
} 


\section{References}

Ahmed K, Tunaru S, Langhans CD, Hanson J, Michalski CW, Kölker S, Jones PM, Okun JG, and Offermanns S (2009a) Deorphanization of GPR109B as a receptor for the beta-oxidation intermediate 3-OH-octanoic acid and its role in the regulation of lipolysis. J Biol Chem 284:21928-21933.

Ahmed K, Tunaru S, and Offermanns S (2009b) GPR109A, GPR109B and GPR81, a family of hydroxy-carboxylic acid receptors. Trends Pharmacol Sci 30:557-562.

Ahmed K, Tunaru S, Tang C, Müller M, Gille A, Sassmann A, Hanson J, and Offermanns S (2010) An autocrine lactate loop mediates insulin-dependent inhibition of lipolysis through GPR81. Cell Metab 11:311-319.

Aktories K, Jakobs KH, and Schultz G (1980a) Nicotinic acid inhibits adipocyte adenylate cyclase in a hormone-like manner. FEBS Lett 115:11-14.

Aktories K, Schultz G, and Jakobs KH (1980b) Regulation of adenylate cyclase activity in hamster adipocytes. Inhibition by prostaglandins, alpha-adrenergic agonists and nicotinic acid. Naunyn Schmiedebergs Arch Pharmacol 312:167-173.

Aktories K, Schultz G, and Jakobs KH (1983) Islet-activating protein prevents nicotinic acid-induced GTPase stimulation and GTP but not GTP gamma S-induced adenylate cyclase inhibition in rat adipocytes. FEBS Lett 156:88-92.

Altschul R, Hoffer A, and Stephen JD (1955) Influence of nicotinic acid on serum cholesterol in man. Arch Biochem 54:558-559.

Benyó Z, Gille A, Bennett CL, Clausen BE, and Offermanns S (2006) Nicotinic acid-induced flushing is mediated by activation of epidermal langerhans cells. Mol Pharmacol 70:1844-1849.

Benyó Z, Gille A, Kero J, Csiky M, Suchánková MC, Nüsing RM, Moers A, Pfeffer K, and Offermanns S (2005) GPR109A (PUMA-G/HM74A) mediates nicotinic acidinduced flushing. $J$ Clin Invest 115:3634-3640.

Bjarnadóttir TK, Gloriam DE, Hellstrand SH, Kristiansson H, Fredriksson R, and Schiöth HB (2006) Comprehensive repertoire and phylogenetic analysis of the G protein-coupled receptors in human and mouse. Genomics 88:263-273.

Boatman PD, Richman JG, and Semple G (2008) Nicotinic acid receptor agonists. J Med Chem 51:7653-7662.

Bodor ET and Offermanns S (2008) Nicotinic acid: an old drug with a promising future. $\mathrm{Br} J$ Pharmacol 153 (Suppl 1):S68-S75.

Boyd AE 3rd, Giamber SR, Mager M, and Lebovitz HE (1974) Lactate inhibition of lipolysis in exercising man. Metabolism 23:531-542.

Brink C, Dahlén SE, Drazen J, Evans JF, Hay DW, Rovati GE, Serhan CN, Shimizu $\mathrm{T}$, and Yokomizo T (2004) International Union of Pharmacology XLIV. Nomenclature for the oxoeicosanoid receptor. Pharmacol Rev 56:149-157.

Brooks GA and Mercier J (1994) Balance of carbohydrate and lipid utilization during exercise: the "crossover" concept. J Appl Physiol 76:2253-2261.

Brown BG, Zhao XQ, Chait A, Fisher LD, Cheung MC, Morse JS, Dowdy AA, Marino EK, Bolson EL, Alaupovic P, et al. (2001) Simvastatin and niacin, antioxidant vitamins, or the combination for the prevention of coronary disease. $N \mathrm{Engl} \mathrm{J} \mathrm{Med}$ 345:1583-1592.

Butcher RW, Baird CE, and Sutherland EW (1968) Effects of lipolytic and antilipolytic substances on adenosine $3^{\prime}, 5^{\prime}$-monophosphate levels in isolated fat cells. $J$ Biol Chem 243:1705-1712.

Cai TQ, Ren N, Jin L, Cheng K, Kash S, Chen R, Wright SD, Taggart AK, and Waters MG (2008) Role of GPR81 in lactate-mediated reduction of adipose lipolysis. Biochem Biophys Res Commun 377:987-991.

Canner PL, Berge KG, Wenger NK, Stamler J, Friedman L, Prineas RJ, and Friedewald W (1986) Fifteen year mortality in Coronary Drug Project patients: longterm benefit with niacin. J Am Coll Cardiol 8:1245-1255.

Capuzzi DM, Guyton JR, Morgan JM, Goldberg AC, Kreisberg RA, Brusco OA, and Brody J (1998) Efficacy and safety of an extended-release niacin (Niaspan): a long-term study. Am J Cardiol 82:74U-81U; discussion 85U-86U.

Carlson LA (1963) Studies on the effect of nicotinic acid on catecholamine stimulated lipolysis in adipose tissue in vitro. Acta Med Scand 173:719-722.

Carlson LA (2005) Nicotinic acid: the broad-spectrum lipid drug. A 50th anniversary review. J Intern Med 258:94-114.

Carlson LA and Oro L (1962) The effect of nicotinic acid on the plasma free fatty acid; demonstration of a metabolic type of sympathicolysis. Acta Med Scand 172:641645.

Cayen MN, Kallai-Sanfacon MA, Dubuc J, Greselin E, and Dvornik D (1982) Evaluation of the lipid-lowering activity of AY-25,712 in rats. Atherosclerosis 45:267279.

Cheng K, Wu TJ, Wu KK, Sturino C, Metters K, Gottesdiener K, Wright SD, Wang Z, O'Neill G, Lai E, et al. (2006) Antagonism of the prostaglandin D2 receptor 1 suppresses nicotinic acid-induced vasodilation in mice and humans. Proc Natl Acad Sci USA 103:6682-6687.

Cherezov V, Rosenbaum DM, Hanson MA, Rasmussen SG, Thian FS, Kobilka TS, Choi HJ, Kuhn P, Weis WI, Kobilka BK, et al. (2007) High-resolution crystal structure of an engineered human beta2-adrenergic $\mathrm{G}$ protein-coupled receptor. Science 318:1258-1265.

Coronary Drug Project Research Group (1975) Clofibrate and niacin in coronary heart disease. Jama 231:360-381.

Costa CG, Dorland L, Holwerda U, de Almeida IT, Poll-The BT, Jakobs C, and Duran M (1998) Simultaneous analysis of plasma free fatty acids and their 3-hydroxy analogs in fatty acid beta-oxidation disorders. Clin Chem 44:463-471.

Cresci GA, Thangaraju M, Mellinger JD, Liu K, and Ganapathy V (2010) Colonic gene expression in conventional and germ-free mice with a focus on the butyrate receptor GPR109A and the butyrate transporter SLC5A8. J Gastrointest Surg 14:449-461.

Deng Q, Frie JL, Marley DM, Beresis RT, Ren N, Cai TQ, Taggart AK, Cheng K, Carballo-Jane E, Wang J, et al. (2008) Molecular modeling aided design of nicotinic acid receptor GPR109A agonists. Bioorg Med Chem Lett 18:4963-4967.

Digby JE, Lee JM, and Choudhury RP (2009) Nicotinic acid and the prevention of coronary artery disease. Curr Opin Lipidol 20:321-326.

DiGirolamo M, Newby FD, and Lovejoy J (1992) Lactate production in adipose tissue: a regulated function with extra-adipose implications. Faseb $J$ 6:2405-2412.
Duncan RE, Ahmadian M, Jaworski K, Sarkadi-Nagy E, and Sul HS (2007) Regulation of lipolysis in adipocytes. Annu Rev Nutr 27:79-101.

Exton JH (1996) Regulation of phosphoinositide phospholipases by hormones, neurotransmitters, and other agonists linked to G proteins. Annu Rev Pharmacol Toxicol 36:481-509.

Fredholm BB (1971) The effect of lactate in canine subcutaneous adipose tissue in situ. Acta Physiol Scand 81:110-123.

Ge H, Weiszmann J, Reagan JD, Gupte J, Baribault H, Gyuris T, Chen JL, Tian H, and $\mathrm{Li} \mathrm{Y}(2008)$ Elucidation of signaling and functional activities of an orphan GPCR, GPR81. J Lipid Res 49:797-803.

Gharbaoui T, Skinner PJ, Shin YJ, Averbuj C, Jung JK, Johnson BR, Duong T, Decaire M, Uy J, Cherrier MC, et al. (2007) Agonist lead identification for the high affinity niacin receptor GPR109a. Bioorg Med Chem Lett 17:4914-4919.

Gille A, Bodor ET, Ahmed K, and Offermanns S (2008) Nicotinic acid: pharmacological effects and mechanisms of action. Annu Rev Pharmacol Toxicol 48:79-106.

Guyton JR (2007) Niacin in cardiovascular prevention: mechanisms, efficacy, and safety. Current Opinion in Lipidology 18:415-420.

Hagström-Toft E, Enoksson S, Moberg E, Bolinder J, and Arner P (1997) Absolute concentrations of glycerol and lactate in human skeletal muscle, adipose tissue, and blood. Am J Physiol 273:E584-E592.

Hanson J, Gille A, Zwykiel S, Lukasova M, Clausen BE, Ahmed K, Tunaru S, Wirth A, and Offermanns S (2010) Nicotinic acid- and monomethyl fumarate-induced flushing involves GPR109A expressed by keratinocytes and COX-2-dependent prostanoid formation in mice. J Clin Invest 120:2910-2919.

Hernandez M, Wright SD, and Cai TQ (2007) Critical role of cholesterol ester transfer protein in nicotinic acid-mediated HDL elevation in mice. Biochem Biophys Res Commun 355:1075-1080.

Hoefnagel JJ, Thio HB, Willemze R, and Bouwes Bavinck JN (2003) Long-term safety aspects of systemic therapy with fumaric acid esters in severe psoriasis. Br J Dermatol 149:363-369.

Hofer AM and Brown EM (2003) Extracellular calcium sensing and signalling. Nat Rev Mol Cell Biol 4:530-538.

Hosoi T, Koguchi Y, Sugikawa E, Chikada A, Ogawa K, Tsuda N, Suto N, Tsunoda $\mathrm{S}$, Taniguchi T, and Ohnuki T (2002) Identification of a novel human eicosanoid receptor coupled to G(i/o). J Biol Chem 277:31459-31465.

Huckabee WE (1958) Relationships of pyruvate and lactate during anaerobic metabolism. I. Effects of infusion of pyruvate or glucose and of hyperventilation. $J$ Clin Invest 37:244-254.

IJzerman AP, Offermanns S, Waters MG, and Wise A (2010) Nicotinic acid receptor family. IUPHAR database (IUPHAR-DB). Available at: http://www.iuphar-db.org/ DATABASE/FamilyMenuForward?familyId $=48$

Imbriglio JE, Chang S, Liang R, Raghavan S, Schmidt D, Smenton A, Tria S, Schrader TO, Jung JK, Esser C, et al. (2009) GPR109a agonists. Part 1: 5-Alkyl and 5-aryl-pyrazole-tetrazoles as agonists of the human orphan G-protein coupled receptor GPR109a. Bioorg Med Chem Lett 19:2121-2124.

Irukayama-Tomobe Y, Tanaka H, Yokomizo T, Hashidate-Yoshida T, Yanagisawa M, and Sakurai T (2009) Aromatic D-amino acids act as chemoattractant factors for human leukocytes through a G protein-coupled receptor, GPR109B. Proc Natl Acad Sci USA 106:3930-3934.

Issekutz B Jr and Miller HI (1962) Plasma free fatty acids during exercise and the effect of lactic acid. Proc Soc Exp Biol Med 110:237-239.

Jaakola VP, Griffith MT, Hanson MA, Cherezov V, Chien EY, Lane JR, Ijzerman AP and Stevens RC (2008) The 2.6 angstrom crystal structure of a human A2A adenosine receptor bound to an antagonist. Science 322:1211-1217.

Jansson PA, Larsson A, Smith U, and Lönnroth P (1994) Lactate release from the subcutaneous tissue in lean and obese men. J Clin Invest 93:240-246.

Jeninga EH, Bugge A, Nielsen R, Kersten S, Hamers N, Dani C, Wabitsch M, Berger R, Stunnenberg HG, Mandrup S, et al. (2009) Peroxisome proliferator-activated receptor gamma regulates expression of the anti-lipolytic G-protein-coupled receptor 81 (GPR81/Gpr81). J Biol Chem 284:26385-26393.

Jones CE, Holden S, Tenaillon L, Bhatia U, Seuwen K, Tranter P, Turner J, Kettle R, Bouhelal R, Charlton S, et al. (2003) Expression and characterization of a 5-oxo-6E,8Z,11Z,14Z-eicosatetraenoic acid receptor highly expressed on human eosinophils and neutrophils. Mol Pharmacol 63:471-477.

Jones PM, Tjoa S, Fennessey PV, Goodman SI, and Bennett MJ (2002) Addition of quantitative 3-hydroxy-octadecanoic acid to the stable isotope gas chromatography-mass spectrometry method for measuring 3-hydroxy fatty acids. Clin Chem 48:176-179.

Joy T and Hegele RA (2008) Is raising HDL a futile strategy for atheroprotection? Nat Rev Drug Discov 7:143-155.

Jung JK, Johnson BR, Duong T, Decaire M, Uy J, Gharbaoui T, Boatman PD, Sage CR, Chen R, Richman JG, et al. (2007) Analogues of acifran: agonists of the high and low affinity niacin receptors, GPR109a and GPR109b. J Med Chem 50:14451448.

Kamanna VS, Ganji SH, and Kashyap ML (2009) The mechanism and mitigation of niacin-induced flushing. Int J Clin Pract 63:1369-1377.

Kamanna VS and Kashyap ML (2008) Mechanism of action of niacin. Am J Cardiol 101:20B-26B.

Kappos L, Gold R, Miller DH, Macmanus DG, Havrdova E, Limmroth V, Polman CH, Schmierer K, Yousry TA, Yang M, et al. (2008) Efficacy and safety of oral fumarate in patients with relapsing-remitting multiple sclerosis: a multicentre, randomised, double-blind, placebo-controlled phase IIb study. Lancet 372:1463-1472.

Knowles HJ, te Poele RH, Te Poole R, Workman P, and Harris AL (2006) Niacin induces PPARgamma expression and transcriptional activation in macrophages via HM74 and HM74a-mediated induction of prostaglandin synthesis pathways. Biochem Pharmacol 71:646-656.

Kontush A and Chapman MJ (2006) Antiatherogenic small, dense HDL-guardian angel of the arterial wall? Nat Clin Pract Cardiovasc Med 3:144-153.

Kostylina G, Simon D, Fey MF, Yousefi S, and Simon HU (2008) Neutrophil apoptosis mediated by nicotinic acid receptors (GPR109A). Cell Death Differ 15:134-142. 
Kreisberg RA (1980) Lactate homeostasis and lactic acidosis. Ann Intern Med 92: $227-237$.

Lai E, Waters MG, Tata JR, Radziszewski W, Perevozskaya I, Zheng W, Wenning L, Connolly DT, Semple G, Johnson-Levonas AO, et al. (2008) Effects of a niacin receptor partial agonist, MK-0354, on plasma free fatty acids, lipids, and cutaneous flushing in humans. J Clin Lipidol 2:375-383.

Lee DK, Nguyen T, Lynch KR, Cheng R, Vanti WB, Arkhitko O, Lewis T, Evans JF, George SR, and O'Dowd BF (2001) Discovery and mapping of ten novel G proteincoupled receptor genes. Gene 275:83-91.

Li G, Shi Y, Huang H, Zhang Y, Wu K, Luo J, Sun Y, Lu J, Benovic JL, and Zhou N (2010) Internalization of the human nicotinic acid receptor GPR109A is regulated by $\mathrm{G}_{\mathrm{i}}$, GRK2, and arrestin3. J Biol Chem 285:22605-22618.

Liu C, Wu J, Zhu J, Kuei C, Yu J, Shelton J, Sutton SW, Li X, Yun SJ, Mirzadegan $\mathrm{T}$, et al. (2009) Lactate inhibits lipolysis in fat cells through activation of an orphan G-protein-coupled receptor, GPR81. J Biol Chem 284:2811-2822.

Lorenzen A, Stannek C, Lang H, Andrianov V, Kalvinsh I, and Schwabe U (2001) Characterization of a G protein-coupled receptor for nicotinic acid. Mol Pharmacol 59:349-357.

Maciejewski-Lenoir D, Richman JG, Hakak Y, Gaidarov I, Behan DP, and Connolly DT (2006) Langerhans cells release prostaglandin D2 in response to nicotinic acid. J Invest Dermatol 126:2637-2646.

Mahboubi K, Witman-Jones T, Adamus JE, Letsinger JT, Whitehouse D, Moorman AR, Sawicki D, Bergenhem N, and Ross SA (2006) Triglyceride modulation by acifran analogs: activity towards the niacin high and low affinity G proteincoupled receptors HM74A and HM74. Biochem Biophys Res Commun 340:482490.

Marbach EP and Weil MH (1967) Rapid enzymatic measurement of blood lactate and pyruvate. Use and significance of metaphosphoric acid as a common precipitant. Clin Chem 13:314-325.

Martin PM, Ananth S, Cresci G, Roon P, Smith S, and Ganapathy V (2009) Expression and localization of GPR109A (PUMA-G/HM74A) mRNA and protein in mammalian retinal pigment epithelium. Mol Vis 15:362-372.

Martres P (2009) HM74a agonists: will they be the new generation of nicotinic acid? Curr Top Med Chem 9:428-435.

McKenney J, Bays H, Koren M, Ballantyne CM, Paolini JF, Mitchel Y, Betteridge A, Kuznetsova O, Sapre A, Sisk CM, et al. (2010) Safety of extended-release niacin/ laropiprant in patients with dyslipidemia. J Clin Lipidol 4:105-112.e1.

Meyers CD, Kamanna VS, and Kashyap ML (2004) Niacin therapy in atherosclerosis. Curr Opin Lipidol 15:659-665.

Morrow JD, Parsons WG 3rd, and Roberts LJ 2nd (1989) Release of markedly increased quantities of prostaglandin D2 in vivo in humans following the administration of nicotinic acid. Prostaglandins 38:263-274.

Niessner H and Beutler E (1973) Fluorometric analysts of glycolytic intermediates in human red blood cells. Biochem Med 8:123-134.

Nomura H, Nielsen BW, and Matsushima K (1993) Molecular cloning of cDNAs encoding a LD78 receptor and putative leukocyte chemotactic peptide receptors. Int Immunol 5:1239-1249.

Nugteren-Huying WM, van der Schroeff JG, Hermans J, and Suurmond D (1990) Fumaric acid therapy for psoriasis: a randomized, double-blind, placebo-controlled study. J Am Acad Dermatol 22:311-312.

Oberwittler H and Baccara-Dinet M (2006) Clinical evidence for use of acetyl salicylic acid in control of flushing related to nicotinic acid treatment. Int J Clin Pract 60:707-715.

Offermanns S (2006) The nicotinic acid receptor GPR109A (HM74A or PUMA-G) as a new therapeutic target. Trends Pharmacol Sci 27:384-390.

Osnes JB and Hermansen L (1972) Acid-base balance after maximal exercise of short duration. J Appl Physiol 32:59-63.

Owen OE, Felig P, Morgan AP, Wahren J, and Cahill GF Jr (1969) Liver and kidney metabolism during prolonged starvation. J Clin Invest 48:574-583.

Palczewski K, Kumasaka T, Hori T, Behnke CA, Motoshima H, Fox BA, Le Trong I, Teller DC, Okada T, Stenkamp RE, et al. (2000) Crystal structure of rhodopsin: a G protein-coupled receptor. Science 289:739-745.

Paolini JF, Mitchel YB, Reyes R, Kher U, Lai E, Watson DJ, Norquist JM, Meehan AG, Bays HE, Davidson M, et al. (2008) Effects of laropiprant on nicotinic acidinduced flushing in patients with dyslipidemia. Am J Cardiol 101:625-630.

Qvisth V, Hagström-Toft E, Moberg E, Sjöberg S, and Bolinder J (2007) Lactate release from adipose tissue and skeletal muscle in vivo: defective insulin regulation in insulin-resistant obese women. Am J Physiol Endocrinol Metab 292:E709E714.

Raghavan S, Tria GS, Shen HC, Ding FX, Taggart AK, Ren N, Wilsie LC, Krsmanovic ML, Holt TG, Wolff MS, et al. (2008) Tetrahydro anthranilic acid as a surrogate for anthranilic acid: Application to the discovery of potent niacin receptor agonists. Bioorg Med Chem Lett 18:3163-3167.

Reich K, Thaci D, Mrowietz U, Kamps A, Neureither M, and Luger T (2009) Efficacy and safety of fumaric acid esters in the long-term treatment of psoriasis-a retrospective study (FUTURE). J Dtsch Dermatol Ges 7:603-611.

Ren N, Kaplan R, Hernandez M, Cheng K, Jin L, Taggart AK, Zhu AY, Gan X, Wright SD, and Cai TQ (2009) Phenolic acids suppress adipocyte lipolysis via activation of the nicotinic acid receptor GPR109A (HM74a/PUMA-G). J Lipid Res 50:908-914.

Richman JG, Kanemitsu-Parks M, Gaidarov I, Cameron JS, Griffin P, Zheng H, Guerra NC, Cham L, Maciejewski-Lenoir D, Behan DP, et al. (2007) Nicotinic acid receptor agonists differentially activate downstream effectors. J Biol Chem 282: 18028-18036.

Schaub A, Fütterer A, and Pfeffer K (2001) PUMA-G, an IFN-gamma-inducible gene in macrophages is a novel member of the seven transmembrane spanning receptor superfamily. Eur J Immunol 31:3714-3725.

Schmidt D, Smenton A, Raghavan S, Carballo-Jane E, Lubell S, Ciecko T, Holt TG, Wolff M, Taggart A, Wilsie L, et al. (2009) Pyrazole acids as niacin receptor agonists for the treatment of dyslipidemia. Bioorg Med Chem Lett 19:4768-4772.
Schweckendiek W (1959) [Treatment of psoriasis vulgaris.]. Med Monatsschr 13: 103-104.

Seki K, Isegawa J, Fukuda M, and Ohki M (1984) Studies on hypolipidemic agents. II. Synthesis and pharmacological properties of alkylpyrazole derivatives. Chem Pharm Bull 32:1568-1577.

Semple G, Skinner PJ, Gharbaoui T, Shin YJ, Jung JK, Cherrier MC, Webb PJ, Tamura SY, Boatman PD, Sage CR, et al (2008) 3-(1H-tetrazol-5-yl)-1,4,5,6tetrahydro-cyclopentapyrazole (MK-0354): a partial agonist of the nicotinic acid receptor, G-protein coupled receptor $109 \mathrm{a}$, with antilipolytic but no vasodilatory activity in mice. $J$ Med Chem 51:5101-5108.

Senior B and Loridan L (1968) Direct regulatory effect of ketones on lipolysis and on glucose concentrations in man. Nature 219:83-84.

Shen HC (2009) Acyl hydroxypyrazoles as novel agonists for high-affinity nicotinic acid receptor GPR109A: WO2008051403. Expert Opin Ther Pat 19:1149-1155.

Shen HC and Colletti SL (2009) Novel patent publications on high-affinity nicotinic acid receptor agonists. Expert Opin Ther Pat 19:957-967.

Shen HC, Ding FX, Deng Q, Wilsie LC, Krsmanovic ML, Taggart AK, Carballo-Jane E, Ren N, Cai TQ, Wu TJ, et al. (2009) Discovery of novel tricyclic full agonists for the G-protein-coupled niacin receptor 109A with minimized flushing in rats. J Med Chem 52:2587-2602.

Shen HC, Ding FX, Luell S, Forrest MJ, Carballo-Jane E, Wu KK, Wu TJ, Cheng K, Wilsie LC, Krsmanovic ML, et al. (2007a) Discovery of biaryl anthranilides as full agonists for the high affinity niacin receptor. J Med Chem 50:6303-6306.

Shen HC, Ding FX, Raghavan S, Deng Q, Luell S, Forrest MJ, Carballo-Jane E Wilsie LC, Krsmanovic ML, Taggart AK, et al. (2010) Discovery of a biaryl cyclohexene carboxylic acid (MK-6892): a potent and selective high affinity niacin receptor full agonist with reduced flushing profiles in animals as a preclinical candidate. J Med Chem 53:2666-2670.

Shen HC, Szymonifka MJ, Kharbanda D, Deng Q, Carballo-Jane E, Wu KK, Wu TJ, Cheng K, Ren N, Cai TQ, et al. (2007b) Discovery of orally bioavailable and nove urea agonists of the high affinity niacin receptor GPR109A. Bioorg Med Chem Lett 17:6723-6728.

Shen HC, Taggart AKP, Wilsie LC, Waters MG, Hammond ML, Tata JR, and Colletti SL (2008) Discovery of pyrazolopyrimidines as the first class of allosteric agonists for the high affinity nicotinic acid receptor GPR109A. Bioorg Med Chem Lett 18:4948-4951.

Skinner PJ, Cherrier MC, Webb PJ, Sage CR, Dang HT, Pride CC, Chen R, Tamura SY, Richman JG, Connolly DT, et al. (2007a) 3-Nitro-4-amino benzoic acids and 6 -amino nicotinic acids are highly selective agonists of GPR109b. Bioorg Med Chem Lett 17:6619-6622.

Skinner PJ, Cherrier MC, Webb PJ, Shin YJ, Gharbaoui T, Lindstrom A, Hong V, Tamura SY, Dang HT, Pride CC, et al. (2007b) Fluorinated pyrazole acids are agonists of the high affinity niacin receptor GPR109a. Bioorg Med Chem Lett 17:5620-5623.

Skinner PJ, Webb PJ, Sage CR, Dang TH, Pride CC, Chen R, Tamura SY, Richman JG, Connolly DT, and Semple G (2009) 5-N,N-Disubstituted 5-aminopyrazole-3carboxylic acids are highly potent agonists of GPR109b. Bioorg Med Chem Lett 19:4207-4209.

Soga T, Kamohara M, Takasaki J, Matsumoto S, Saito T, Ohishi T, Hiyama H, Matsuo A, Matsushime H, and Furuichi K (2003) Molecular identification of nicotinic acid receptor. Biochem Biophys Res Commun 303:364-369.

Stern RH, Spence JD, Freeman DJ, and Parbtani A (1991) Tolerance to nicotinic acid flushing. Clin Pharmacol Ther 50:66-70.

Taggart AK, Kero J, Gan X, Cai TQ, Cheng K, Ippolito M, Ren N, Kaplan R, Wu K, Wu TJ, et al. (2005) (D)-beta-Hydroxybutyrate inhibits adipocyte lipolysis via the nicotinic acid receptor PUMA-G. J Biol Chem 280:26649-26652.

Tang H, Lu JY, Zheng X, Yang Y, and Reagan JD (2008) The psoriasis drug monomethylfumarate is a potent nicotinic acid receptor agonist. Biochem Biophys Res Commun 375:562-565.

Tang Y, Zhou L, Gunnet JW, Wines PG, Cryan EV, and Demarest KT (2006) Enhancement of arachidonic acid signaling pathway by nicotinic acid receptor HM74A. Biochem Biophys Res Commun 345:29-37.

Taylor AJ, Sullenberger LE, Lee HJ, Lee JK, and Grace KA (2004) Arterial Biology for the Investigation of the Treatment Effects of Reducing Cholesterol (ARBITER) 2: a double-blind, placebo-controlled study of extended-release niacin on atherosclerosis progression in secondary prevention patients treated with statins. Cir culation 110:3512-3517.

Taylor AJ, Villines TC, Stanek EJ, Devine PJ, Griffen L, Miller M, Weissman NJ, and Turco M (2009) Extended-release niacin or ezetimibe and carotid intimamedia thickness. $N$ Engl J Med 361:2113-2122.

Thangaraju M, Cresci GA, Liu K, Ananth S, Gnanaprakasam JP, Browning DD, Mellinger JD, Smith SB, Digby GJ, Lambert NA, et al. (2009) GPR109A is a G-protein-coupled receptor for the bacterial fermentation product butyrate and functions as a tumor suppressor in colon. Cancer Res 69:2826-2832.

Trudeau F, Bernier S, de Glisezinski I, Crampes F, Dulac F, and Rivière D (1999) Lack of antilipolytic effect of lactate in subcutaneous abdominal adipose tissue during exercise. J Appl Physiol 86:1800-1804

Tunaru S, Kero J, Schaub A, Wufka C, Blaukat A, Pfeffer K, and Offermanns S (2003) PUMA-G and HM74 are receptors for nicotinic acid and mediate its antilipolytic effect. Nat Med 9:352-355.

Tunaru S, Lättig J, Kero J, Krause G, and Offermanns S (2005) Characterization of determinants of ligand binding to the nicotinic acid receptor GPR109A (HM74A PUMA-G). Mol Pharmacol 68:1271-1280.

Turrell ES and Robinson S (1942) The acid-base equilibrium of the blood in exercise Am $J$ Physiol 137:742-745.

van der Hoorn JW, de Haan W, Berbée JF, Havekes LM, Jukema JW, Rensen PC, and Princen HM (2008) Niacin increases HDL by reducing hepatic expression and plasma levels of cholesteryl ester transfer protein in APOE*3Leiden.CETP mice. Arterioscler Thromb Vasc Biol 28:2016-2022.

van Herk T, Brussee J, van den Nieuwendijk AM, van der Klein PA, IJzerman AP, 
Stannek C, Burmeister A, and Lorenzen A (2003) Pyrazole derivatives as partial agonists for the nicotinic acid receptor. J Med Chem 46:3945-3951.

Walters RW, Shukla AK, Kovacs JJ, Violin JD, DeWire SM, Lam CM, Chen JR, Muehlbauer MJ, Whalen EJ, and Lefkowitz RJ (2009) beta-Arrestin1 mediates nicotinic acidinduced flushing, but not its antilipolytic effect, in mice. J Clin Invest 119:1312-1321.

Warne T, Serrano-Vega MJ, Baker JG, Moukhametzianov R, Edwards PC, Henderson R, Leslie AG, Tate CG, and Schertler GF (2008) Structure of a beta1adrenergic G-protein-coupled receptor. Nature 454:486-491.

Wise A, Foord SM, Fraser NJ, Barnes AA, Elshourbagy N, Eilert M, Ignar DM, Murdock PR, Steplewski K, Green A, et al. (2003) Molecular identification of high and low affinity receptors for nicotinic acid. J Biol Chem 278:9869-9874.
Yousefi S, Cooper PR, Mueck B, Potter SL, and Jarai G (2000) cDNA representational difference analysis of human neutrophils stimulated by GM-CSF. Biochem Biophys Res Commun 277:401-409.

Zellner C, Pullinger CR, Aouizerat BE, Frost PH, Kwok PY, Malloy MJ, and Kane JP (2005) Variations in human HM74 (GPR109B) and HM74A (GPR109A) niacin receptors. Hum Mutat 25:18-21.

Zhou L, Tang Y, Cryan EV, and Demarest KT (2007) Human epidermoid A431 cells express functional nicotinic acid receptor HM74a. Mol Cell Biochem 294:243-248. Zingoni A, Rocchi M, Storlazzi CT, Bernardini G, Santoni A, and Napolitano M (1997) Isolation and chromosomal localization of GPR31, a human gene encoding a putative G protein-coupled receptor. Genomics 42:519-523. 